\title{
Mineral Resource Governance in the 21st Century and a sustainable European Union
}

\author{
Patrice Christmann ${ }^{1}$
}

Published online: 21 April 2021

(C) The Author(s), under exclusive licence to Springer-Verlag GmbH Germany, part of Springer Nature 2021

\begin{abstract}
Minerals and metals are ingredients necessary for the production of multiple goods and services that are essential to contemporary societies, feeding frequently complex global supply chains. The development of the modern, material-intensive lifestyles has led to a formidable acceleration of their production, particularly since the middle of the 20th century. Despite all the progress that can and needs to be done towards a circular, resource-efficient global economy, several important trends including:
\end{abstract}

- demographic growth (United Nations 2019),

- the rapid development of the global middle class (Kharas

2017),

- growing urbanisation (United Nations 2018) and

- the transition towards a low-carbon global economy

(Hund et al. 2020)

point towards a continued, exponential growth of the global demand and production of minerals and metals (Christmann 2017; Elshkaki et al. 2018; Halada et al. 2008; Hund et al. 2020; Schipper et al. 2018). Despite the efforts made by some producers and some authorities to strengthen the already important contribution of the minerals and metals industry to the UN Sustainable Development Goals (SDGs), the production of minerals and metals has negative impacts both on the global and on local ecosystems. It already contributes to $16 \%$ of global $\mathrm{CO}_{2}$ emissions (OECD 2019) and it generates about 50 bn t solid waste per year, 25 times the estimated annual amount of urban waste (Franks et al. 2021). This waste is composed of mostly barren rock fragments, essentially overburden that needed to be stripped to access the ore, and of fine-grained ore processing tailings. The latter, if containing sulphides such as pyrite and residual minerals containing elements such as arsenic, cadmium, mercury, selenium or tellurium, can become highly problematic for the well-being of future generations. The production of minerals and metals also can be a source of conflicts and of social disruption. Failure to globally and sustainably manage the production of minerals and metals, in a transparent and multilateral framework providing a stable, foreseeable and level playing field for investors and for trade, could limit the capacity of the industry to reply to future demand and lead to potentially disastrous global conflicts. Depending on the practices of individual producers, on the quality of national and/or regional regulatory frameworks and on the effectiveness of their implementation, a same mineral or metal can be produced under very differing environmental and social conditions. Despite progress on sustainability performance reporting and of transparency of some parts of the industry, end-users of minerals and metals do not know how the minerals and metals they use have been produced and they hardly can choose among various supply sources, although from a sustainability perspective there are great differences among the practices of individual producers. The development of an international governance framework to support the development of transparency and verifiable corporate accountability, to foster research and innovation to reduce the negative impacts of the industry and to provide incentives rewarding pro-sustainability action, is called for.

Patrice Christmann

krysmine@gmail.com

1 Krysmine, Sandillon, France 
Support to document and disseminate best practice and best available technologies as well as to strengthen the global institutional capacities to manage this very complex and vital industry is needed. This could be an important role for a future International Minerals and Metals Agency. So far, only the exploration and mining of deep-sea mineral deposits located in international zones of the oceans are internationally regulated under the UN Convention On the Law Of the Sea (UNCLOS), with a specific International Agency in charge of its implementation and of the provision of scientific and technical guidance: the International Seabed Authority (Kingston, Jamaica), created in 1994. The European Union could and should play an important role in these developments as it is an important global end-user of minerals and metals mostly produced outside its borders. The EU's environmental footprint outside its borders is very high and growing. According to EUROSTAT trade data, EU imports of goods from beyond its borders doubled in value from 2002 to 2018, with China's share having grown by over $460 \%$ over this period, representing $19 \%$ of the total imports of goods. China is the world largest greenhouse gas emitter. EU's very strong point is its long history of successful research and innovation, dating back to the Renaissance (15th Century BCE). Its very large and highly qualified human resources in science and innovation much benefits from progressive European-scale structuration and integration of mineral- and metal-related research and innovation thanks to the European Union raw material-related policies developed since 2008 (European Commission 2008) under the EU Raw Materials Initiative (see p. 20 ff.). The EIT Raw Materials, launched in 2015, is the world largest organised and funded mineral- and metal-related innovation network, linking over 120 partners from academia, industry and research organisations (EIT Raw Materials, 2021). But, despite these positive developments, it so far lacks the legal basis to develop its own mineral resource policy and its own homogeneous regulatory framework. It nevertheless can act in different areas that are linked to the development of a global, minerals and metals industry based on sustainable development principles through its capacity to act as European Union in domains such as development cooperation, energy, environment, higher education, research and innovation, as well as trade. It will require long-term vision and political leadership to develop and implement a sustainable EU raw materials policy that would also act as a catalyst for the development of much needed global minerals and metals governance. The publication by the European Commission, in September 2020, of its Action Plan on Critical Raw Materials, part of the European Raw Materials Initiative launched in 2008, could be an important step to address the issues outlined in this paper.

Keywords Minerals · Metals · Sustainable development · Policies · Regulations · International Minerals and Metals Agency · European Union · World

\section{Mineral Resource Governance in the 21st century: a necessity}

There are many definitions of governance. In relation to mineral resources and to the minerals and metals industry, it can be defined as the framework of laws, regulations, voluntary initiatives, standards, norms, practices and institutions that is applied by the stakeholders concerned by this industry and any of its specific projects. Governance requires an effective, verifiable implementation and the commitment to this framework of all stakeholders with an interest in a specific project or activity. Mineral resource governance can be a very abstract, if not vague, concept. It can also explicitly refer to, and should systematically do it, the UN Sustainable Development Goals internationally agreed in 2015 (United Nations 2016; UN International Resource Panel 2020b). It also should refer to the need to decouple economic growth from the negative impacts of growth on the life supporting global ecosystem, of which climate, healthy oceans and the global carbon and water cycles are essential components. Decoupling is also needed to reduce the current high pressure on the great diversity of local ecosystems (UN International Resource Panel 2011) on which local life depends on.

The squandering of mineral rents by the political "elites" in some mineral-rich countries, corruption, short-term profit seeking, tax evasion, the lack of public transparent reporting of exploration projects and mining activities are still obstacles to the development of good governance. While governments of developed rich countries, including the EU, bear a significant responsibility for this state of affairs, individual choices and behaviours are equally important. Everyone needs to understand the multiple roles of minerals and metals in support of individual well-being and realise their strategic importance, while supporting all the efforts needed to develop greater resources circularity, through multiple possible actions such as the eco-efficient production of minerals and metals, and ecodesign of product actions including the following:

- Ecologically and socially efficient production of minerals and metals

- The development of actions that support circular resources use such as: 
- conceiving innovative resources efficient materials

- conceiving serviceable and recyclable goods thanks to eco-design

- the development of the re-use, refurbishment and remanufacturing of specific components and end-of-life recycling

- the fight against programmed obsolescence; industrial ecology where the waste of one industry is used as a resource for another one

Governance is the fourth dimension of sustainable development, in addition to the economic, environmental and social dimensions more widely used to describe sustainable development (Barbier 1987; Purvis et al. 2019; Weinberger et al. 2015). This is why the public reporting by companies of their performance in these four dimensions of sustainability should become a must, and be available for each production site. This is far from the current practice. Governance is the force that drives the convergence of the economic, environmental and social dimensions of sustainable development (Fig. 1). It is not a natural force, but a complex cultural construct based on components such as facts-based knowledge, technological choices, accountability, full public reporting of sustainability performance at individual production sites, transparency and verifiability of data and information.

Data, information and knowledge shared in an open, transparent way among all concerned stakeholders promotes trust, a key ingredient to make complex, risky projects possible.

The minerals and metals industry consists of a complex realm of enterprises that extract raw mineral resources and process them to marketable products, such as sand, cement, aluminium, phosphoric acid, copper, indium or neodymium, needed by the myriad of industrial supply chains (Fig. 2) that are dependent on minerals or metals for the production of goods or services essential to human well-being. For instance,

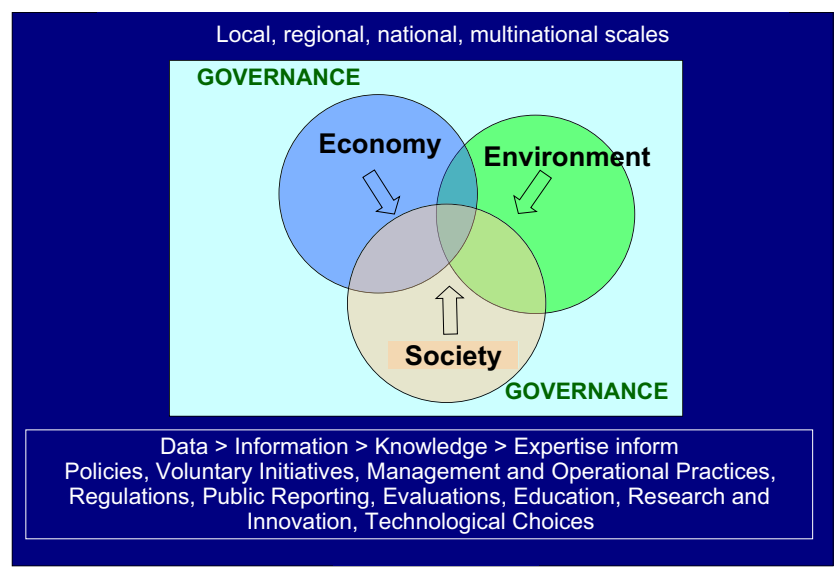

Fig. 1 Governance, the driving force is the fourth dimension of sustainable development, and its key components with regard to the minerals and metals industry minerals and metals are the enablers of the information and communication technologies that allow many to work from home during the COVID-19 pandemic, thus avoiding an even worse economic and social disasters. A recent UN International Resource Panel (IRP) video documents this (IRP 2020a)

A detailed description of this realm, of its multiple stakeholders and of its governance landscape, is provided in a recent report of the IRP (IRP 2020b). It identified about 90 different natural resources government instruments, recognising that some may have been missed by the analysis. None fully addresses the four dimensions of sustainable development, of which governance is one.

This industry is extremely diversified, ranging from

- informal, frequently unregulated or very loosely regulated, sometimes illegal, small-scale entities (some being temporary groupings of fortune seekers without any legal status) with almost no capital and very limited knowledge, using very simple technologies such as digging with picks and shovels and some coarse gravimetric recovery of the marketable mineral product. Loosely regulated, if regulated at all, extraction activities are playing a major role, in many countries, in the production of construction materials (clays, anhydrite and gypsum, sand, lime, gravel, dimension and ornamental stone). The cumulated production of these entities is also an important source of gold, gemstone, tantalum and tin;

- to very large size multinational companies with a market value that exceeded 100 billion \$ US in July 2020 for two of them, BHP and RioTinto (Mining.com 2020). Such companies are knowledge and technology intensive and use state-of-the-art technologies in exploration, mining engineering, ore processing and metallurgy, with complex machinery and processes applied for the recovery of the marketable products. Continuous optimisation of their operations made possible thanks to the intensive use of multiple sensors and of information, and communication technologies are essential in this segment of the industry. These companies and the very large deposits they exploit play a major role in the supply of the global economy with mineral raw materials requiring complex, capital and technology-intensive, industrial processes for their production. While large deposits can be mined by small operations, the huge growing minerals and metals requirements of the global economy make large-scale mining of large deposit essential. Many of these raw materials are needed in tonnages counted in millions of tonnes (e.g. copper, manganese, nickel, lead, phosphate or zinc), or even exceeding the billion tonnes mark (cement, iron ore, steam and coking coal). The per-ton value of these raw materials economically makes them widely traded goods that travel by 
Fig. 2 Schematic representation of a mineral resource-dependent supply chain (derived from IRP 2020b). The EU economy is highly dependent on imports of minerals and metals from beyond its borders and vulnerable to rapid price escalations and possible supply tensions/disruptions. Its vulnerability appears somewhat reduced at the metallurgical and metal-refining stages

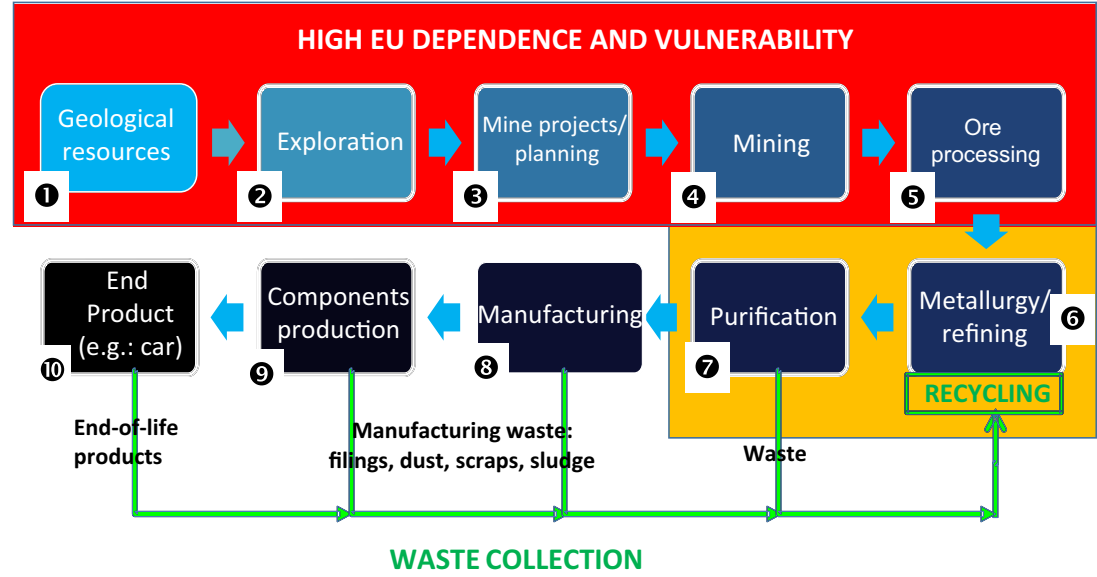

sea over many thousands of kilometres, as it is the case with Brazilian iron ore or Chilean copper concentrates feeding Chinese smelters, while mineral raw materials needed by the construction sector (sand and gravel, ordinary clay, dimension stone) represent about, by far, the largest segment of the mineral production materials produced in the largest tonnages, the world sand and gravel production alone being estimated to be about 40 billion tons per year, GAIN (2014).

- In between, a realm of mid-sized companies plays an important role in the production of many minerals and metals.

- The article by Ericsson and Hodge in this issue provides a detailed presentation of the structure of the global mining industry.

While the locations of the initial stages of mineral resource-dependent supply chains, up to and including ore processing (where needed), are geographically constrained by the geological factors that control the development of economically recoverable concentrations of minerals, the further stages, or nodes, of mineral dependent supply chain can be located in any location worldwide offering "attractive" conditions for the investments necessary to develop the activity and for running it at a profit. The copper industry case documented by Tercero Espinoza et al. (2016) illustrates the global and complex nature of mineral raw material-dependent supply chains.

"Attractive" as used here can mean the availability of cheap and abundant energy, of skilled manpower, of good transport infrastructure and of a stable regulatory and fiscal framework. It can also mean lax environmental, social and/or fiscal regulations, openness to corruption and poor social standards. Profit is usually measured in terms of return on capital invested, after taking into account the multiple risks inherent to mineral and metal production activities (EY 2020). In this annual survey of risk perception by top executives from the global mining industry, "License to operate" ranks as the most important, for the second year in a row. This means that many industry leaders are worried about seeing their operations challenged by their broader stakeholder groups (Fig. 3) such as local populations environmentally and/or socially impacted by mining activities.

Minerals and metals provide a huge range of services and products that are essential to human well-being. Without mineral fertilisers and agricultural machinery, agricultural production would be much reduced, modern water supply and wastewater would not exist, modern health services would be unavailable, nor would the Internet of computers exist.

Their production provides major contributions to the United Nations Sustainable Development Goals (SDGs) (Columbia Center on Sustainable Investment 2016; ICMM 2016) but it also can be a source of important negative environmental and social impacts.

\section{Environmental impacts}

The main impacts of concern are global $\left(\mathrm{CO}_{2}\right.$ emissions that contribute to global warming) or, mostly, local (generation of large amounts of potentially harmful solid waste, failure risk of waste containment structures, impacts on air quality, ground and surface water, on flora and fauna):

- $\mathrm{CO}_{2}$ emissions: the production of minerals and metals generates about $16 \%$ of the global $\mathrm{CO}_{2}$ emissions (OECD 2019), the major contributors being cement and steel, due to the large tonnages produced, and aluminium, whose production is highly energy intensive. $\mathrm{CO}_{2}$ and other emissions are not only the consequence of technological choices made at individual sites; they also are a consequence of the energy mix used for the production of minerals and metals. In 2019, China, by far the most important current global producer of many minerals and metals (Fig. 4), used $85 \%$ of carbon-based fuels in its energy mix, $58 \%$ of the mix being from very polluting coal. In comparison the USA, used only $12 \%$ coal and 
Fig. 3 Minerals and metals industry stakeholders - Source: Christmann (2017) and IRP (2020)

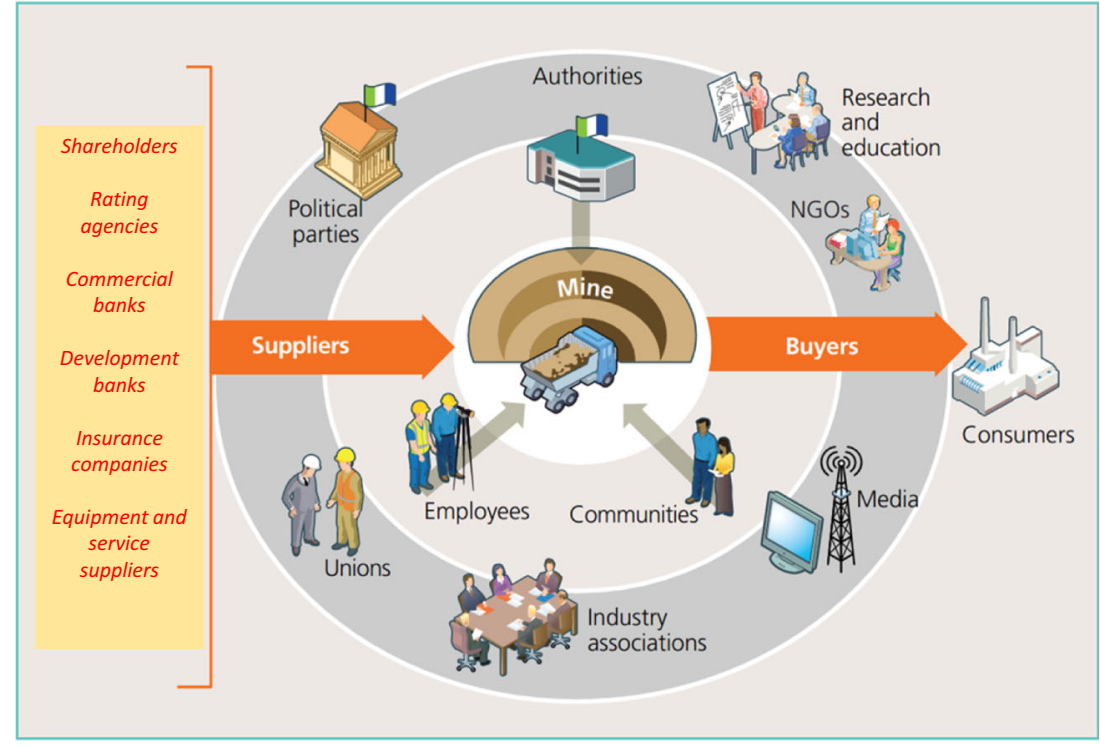

Europe only $14 \%$ in their energy mix (bp 2020). Coal is not only a source of greenhouse gas emissions but also an important source of mercury emissions in the atmosphere (UN Environment 2019) and of massive amounts of environmentally problematic waste from coal burning (fly ash, bottom ash, boiler slag). Some of this waste can be used as a feed for other industrial processes, for instance fly ash in cement production.

- Generation of potentially harmful solid waste and related hazards: the production of some metals (copper, gold, platinum group metals, lead and zinc, phosphate, uranium) generates large amounts of waste, mostly as fine-grained sand like tailings resulting from the crushing and grinding of the ore necessary for the recovery of the valuable minerals from the ore mineral assemblage. These tailings can contain residual minerals, especially sulphides, that are potential sources of harmful elements releases to the environment (such as arsenic, cadmium, mercury, selenium or tellurium) further to a widespread bioleaching process known as Acid Mine Drainage (Verburg et al. 2009; Jacobs et al. 2014; Kesler and Simon 2015; Australian Government 2016; Lottermoser 2017). At an average of $0.56 \% \mathrm{Cu}$ in the globally produced copper ore (Schodde 2019) and assuming a $100 \%$ recovery rate (the reality being probably about 80 to $90 \%$ ), and a global mine copper production of $20.5 \mathrm{Mt} \mathrm{Cu}$ in 2018 , about 3.6 billion tonnes of tailings will have been produced that year. This soft material is stored in large tailing ponds confined by dams. Tailing dams can be very large facilities, extending over several square kilometres. After many years of decline, the average global $\mathrm{Cu}$ content of mined ores may marginally increase (to $0.65-0.7 \%$ $\mathrm{Cu}$ in the globally mined ore if the production from new high-grade deposits in the Democratic Republic increases by 1 to $2 \mathrm{Mt} \mathrm{Cu}$ per year). This would not significantly modify the annual tailings tonnage estimate given here.

Mining and ore processing waste-related impacts can last for many years, even centuries, after the actual termination of mineral and metal production activities. Their mitigation can be the source of important costs to unsuspecting taxpayers, long after the closure of the mining site. In extreme cases, the capital cost needed to manage them at one single derelict mine site can be nearly one billion US\$. This is the cost of the planned confinement of 237,000 tons of deadly arsenic trioxide left behind in underground mined out chambers as a non-marketable by-product resulting from ore processing over the lifetime of the Giant Gold Mine, located near Yellowknife in Canada's North-West Territories (Mckenzie Valley Review Board 2013). This province has a population of only about 45,000 persons. These are few shoulders to bear such a burden. In addition, annual operating costs will accrue for an unspecified number of years.

- Older tailing dams can contain economically important metal contents, sufficient to profitably reprocess them to recover valuable contents. Such reprocessed tailing materials can become suitable for construction purposes. Reprocessing of old tailings can be economically very attractive as in the past the processes used for ore beneficiation were less efficient than in modern state-of-the art processing plants, with significant parts of the ore minerals ending up in the tailings. Where no further economic use is possible for tailing materials, or contained residual 


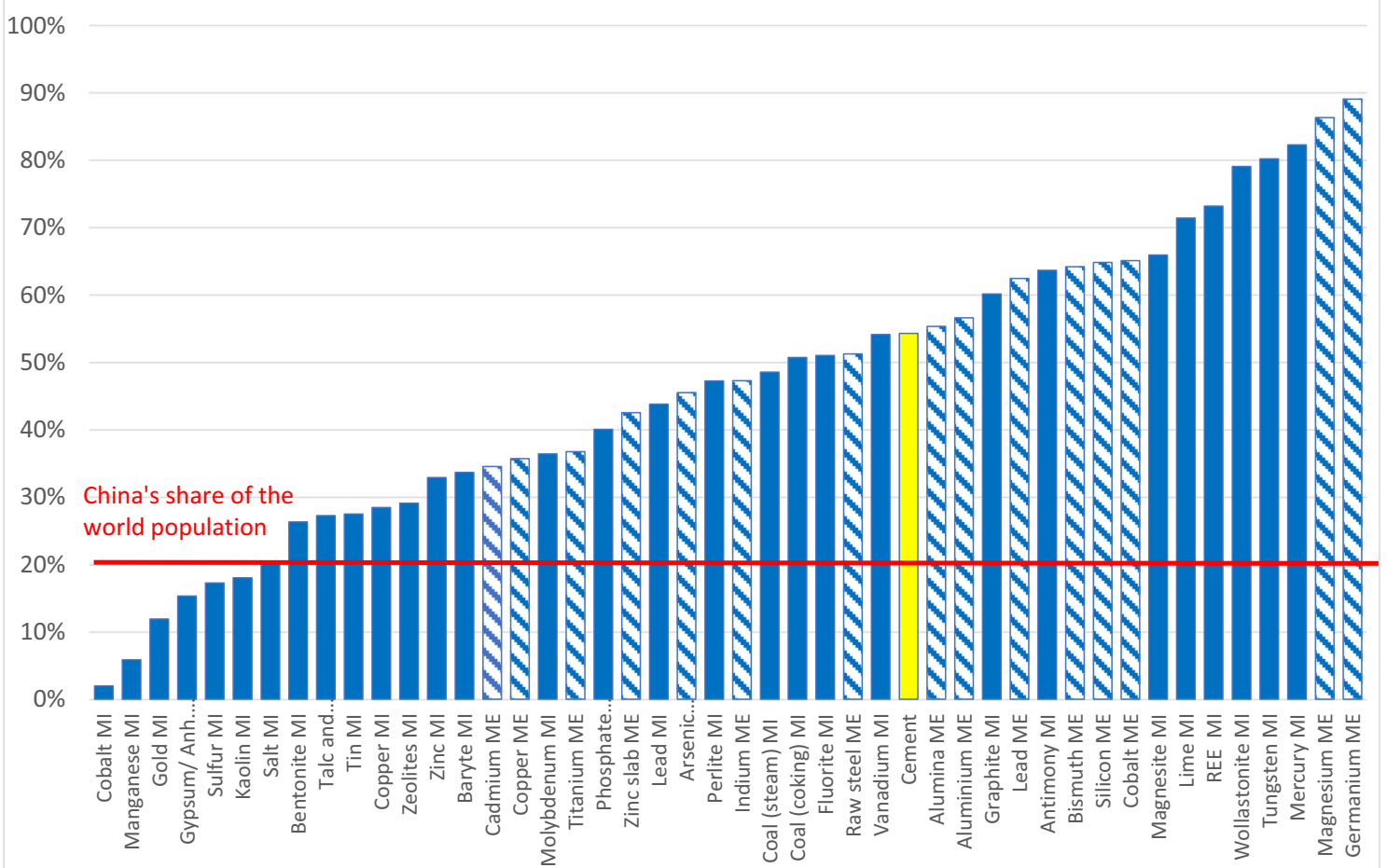

Fig. 4 China's share, in \%, of the 2018 world production, of selected mineral raw materials. China is the world's largest producer of the selected raw materials. The share is shown either as a percentage of the production at mine level (raw material name followed by MI, blue bars) or of metal at smelter/refinery level (name followed by ME, bars with a

metal values are too low to make them economically recoverable, they need to be disposed forever.

- In well-regulated countries and/or in the case of companies operating to high environmental standards, tailings and mine waters are managed to avoid environmental impacts and tailing dams' stability is regularly monitored; nevertheless, tailing ponds can remain long-term threats to the environment as some day after the end of the operation monitoring operations and/or water treatment operations may become underfunded, or no more funded at all, leaving local communities to bear the consequences of industrial activities that may have happened several generations before.

Tailing dams are also fragile structures that may fail with dramatic consequences, even during the active mining phase, as dramatically documented by the Córrego do Feijão iron ore mine tailing dam (Near Brumadinho, Brazil) catastrophic failure that killed at least 259 persons and caused important environmental damage on January 25, 2019 (Silva Rotta et al. 2020). The WISE-Uranium project maintains a database of major tailing dam accidents, listing 150 major tailing dam failures that happened since 1961 with their known consequences (Diehl 2020). diagonal pattern). Cement is shown in yellow as it is neither a mining product nor a metal. Data sources: Darton Commodities Limited (2020), International Copper Study Group (2020), Reichl and Schatz (2020), U.S. Geological Survey (2020)

Concerns about the lasting and potentially very costly impacts of mining activities are on the rise, even in jurisdictions historically favourable to mining. Authorities, wary of the potential negative impacts of mining activities, are imposing tougher regulations on mining activities. In Canada, for instance, the large-scale Schaft Creek open-pit copper mine project in British Columbia, with a measured and indicated resource of about 3.3 Mt Cu (Copper Fox Metals 2020), with molybdenum, gold and silver as by-products, started its mandatory environmental assessment process in 2006, producing over 50 studies, without having obtained the necessary Environmental Assessment certificate so far. In Alaska, the Pebble Mine project acquired by Northern Dynasty Minerals in 2001, is one the world largest undeveloped but fully documented copper resources, with an indicated and measured copper resource of nearly $26 \mathrm{Mt}$. The project has not yet received the required US Environmental Protection Agency permit and it may well never get out of high-level political concerns about its potential impacts on the water quality of Bristol Bay, considered the world's most valuable salmon fishery (Randall 2020).

There is abundant scientific literature on environmental issues related to the production of minerals and metals, for instance UN International Resource Panel (IRP 2013a); 
Kesler and Simon (2015); Jain et al. (2016); and Lottermoser (2017).

Unless there is a broad social consensus to accept lifestyles independent from minerals and metal use, enjoying living conditions equivalent to about 10000 years ago, before the use of metals began to shape the evolution of civilisations, it needs to be accepted by society that there cannot be mineral and metal production without some environmental impact, as much as there are no other human activities without environmental impacts. But these impacts can be much reduced by using the current best available technologies and management practices in mineral and metal production (European Commission 2013a, 2013b, 2017; Garbarino et al. 2018). While companies active all along mineral- and metal-related supply chains have a responsibility in ensuring that the minerals and metals they produce or use are produced according to high sustainability standards, the role and the responsibility of governments, or, in the case of the European Union, of the European institutions, are of major importance too. They ought to ensure that:

- best available technologies and practices are documented and effectively implemented;

- environmental impacts are transparently documented and publicly reported;

- regulations are put in place, and effectively enforced, to ensure that minerals and metals produced on the national territory, or imported, as well as derived goods, are produced in line to best available environmental and social regulations or standards; and

- market mechanisms are put in place to support high environmental and social performance and deter poor practice.

\section{Social impacts}

The production of minerals and metals generates direct and indirect employment in regions that may have only limited development alternatives. Modern large-scale mines, smelters and refineries offer a great diversity of skills in disciplines such as accounting, blasting, chemical analysis, community relations, electrical systems, environmental management, geology, hydraulics, advanced information technologies, mechanics, metallurgical and mining engineering, ore processing, robotics and automation, advanced information and communication technologies, and ventilation management. Most of the skills developed in mining or metallurgical industry are transferrable to other sectors of the economy once a mine or a smelter closes.

The development of human skills needed for the production of minerals and metals has played a critical role in the development of the economic and social wealth of developed nations, and in many cases mining schools are still among the best engineering high schools and research institutions in countries where there is not much mining left. In this respect, mining and metallurgy are important development drivers, the resulting skills development being an important example of the long-lasting social benefits that can result from the transformation of natural capital into social capital. The industrialscale production of minerals and metals involves many stakeholders (Fig. 3), some being directly involved with the productive activities such as:

- professionals working at the mines and the related plants (mineral processing plants and, in some cases, smelters and refineries),

- trade unions,

- local communities that are directly impacted by these activities,

- investors having invested into their development (shareholders, investment and/or development banks) and

- authorities at local, regional and national levels.

Some other stakeholders are equally important, although they are not directly involved in the daily operations. These include academia and research, media, political parties, nongovernmental organisations, insurance companies, technology providers, customers and end-users of minerals and metals. This creates extremely complex webs of differing and potentially conflicting perceptions and interests, fuelled by differing experiences and knowledge, and divergent interests. The differences in perceptions is nurtured by differing cultural differences, access to knowledge and asymmetries of information. Some stakeholders may also reject fact-based evidence and science as guides available to inform their own decisions or even develop rejection of science-based governance. A further complication is that different stakeholders have agendas defined by very different timeframes: economic stakeholders frequently have very short-time strategic objectives set by shareholders expectations of rapid returns. Activist funds and financial analysts being driven by profit seeking are making it difficult for companies to invest in long-term development activities, including in research and innovation. Politicians and regulatory frameworks they define are constrained by electoral agendas while innovations may take decades to complete the complex route from the initial innovation concept and its translation in derived innovative products and services becoming available on the market. Local populations also tend to expect rapid tangible returns from new mining activities.

These conflicting time horizons is an important problem for mining projects which frequently take 20 years and more from the initial discovery to the eventual commissioning of a new mine. And then, the profitability of mining projects that in many cases have required hundreds million $\$$ US, and sometimes billions, of initial capital investment to start their 
production will much depend on hardly foreseeable changes in regulatory and/or taxation frameworks.

Negative social impacts easily develop where modern industrial scale mining projects develop in regions with native populations having had limited, or none, previous exposure to 21 st industrial culture. Cultural differences and knowledge/ information asymmetries between mining companies and local communities can make stakeholder dialogue and cooperation very difficult and resource consuming. But the cost of failure is much higher. It can ruin a project or even translate into bloody conflict. Examples of such situations are the civil war that developed on Bougainville Island (Papua New Guinea) further to the development of the giant Panguna copper mine (May 1996; Hammond 2012; Zorn 2018), the failure of the large-scale Minas Conga gold project in Peru (Downs et al. 2020). Not only large-scale industrial projects are exposed to conflicts. The production of sand and gravel is essentially ensured worldwide by a myriad of small- to mediumscale enterprises, with relatively limited international trade, as compared to higher value minerals and metals, due to the relatively low per-ton value of most sand and gravel products. In quite a number of countries, this specific segment of the industry is very loosely regulated, if regulated at all (Brown and Peduzzi 2019). In some countries, including in Europe, this industry is exposed to corruption and even organised crime and land-use conflicts related to sand and gravel production abound. However, practical solutions are available to reduce the negative impacts of this industry segment (UN Environment 2018). The re-use of tailing sands could help to substitute some sand uses, but this is unlikely to develop significantly unless well-recognised international standards are developed certifying that candidate tailing materials meet minimum physical and chemical specifications required for specific end-uses. Moreover, the use of tailing sands is likely to be constrained by the existence of local markets, as their low per-ton value makes it uneconomic to transport such materials over longer distances.

All are challenging top-down business-as-usual development models, calling for careful stakeholder integration from the early stages of the mine planning process, as soon as exploration results indicate that a discovery may have the potential to become a mine and the decision is taken by the project owners to engage a preliminary economic assessment or a scoping study of the identified prospect.

Addressing in a fair and transparent manner the multiple interests of stakeholders is a complex and time-consuming, but necessary, process. Even the well-meant goodwill of companies keen to engage local communities into their project can lead to negative impacts. In regions with limited economic activities, mining projects do provide jobs and financial compensations to impacted communities, but these are temporary as employment, local communities support programmes and/ or compensation schemes paid by mining companies are likely to come to a more or less rapid stop once the mine and/or the smelter/refinery end their activities. Income and/ or benefits perceived by local communities can be temporary by nature, unless specific actions are conceived and effectively implemented such as the creation of a public trust fund where part of the funds perceived by the authorities is set aside for the benefit of future generations, a model that has been develop for oil and gas revenue in Norway, with a large part of this revenue being set aside in the Norwegian Oil Trust Fund, currently worth over 1 trillion US\$ (Norges Bank Investment Management 2019).

As mineral and metal production-related revenue comes to an end once the production activities, social disruption can be extremely severe when communities adopted unsustainable lifestyles that then collapsed. Zorn (2018) reflecting on his long experience in advising the authorities of Papua New Guinea authorities on the management of the country's mining sector states: "Big mining projects in developing countries by their very nature generate lots of cash, environmental problems, and social disruption while contributing relatively little employment or other linkages to the national economy. Managing both the good (foreign exchange inflows, government revenue) and the bad is not easy".

Ericsson and Löf (2019) and the International Council of Mines and Metals (ICMM 2020) provide descriptions of the contribution of mining to national economies, including production, prices, mineral rents, exploration expenditure, government revenues and several governance-related indicators, including the World Bank's World Governance Indicator (WGI) and the UN Human Development Index (HDI). The geographic coverage is global, with a particular focus on lowincome and middle-income countries. This contribution, from a broad sustainability perspective, has also been assessed by the UN International Resource Panel (IRP 2020b).

However, the use of mineral rents, an indicator published annually by the World Bank as a part of its World Development Indicators (World Bank 2021), does not document the contribution of mining to national economies. A mineral rent is the financial surplus that arises if the selling price of a mineral or mineral production is higher than the full cost of its production, including taxes, royalties and levies, amortisation and depreciation. This indicator provides no information about how this rent is shared among the various stakeholders.

To measure the contribution of mineral and metal production to producing countries, it would be necessary to consider all the monetary flows that go into the economy of the producing country:

- Wages paid to national employees

- Procurement from national sources (including food, energy, and water) 
- Taxes, levies, rights, and royalties paid to the national, regional or local authorities

- Voluntary subsidies and grants paid to local stakeholders (support to specific local activities related, for instance, to culture, education, farming, health or sports)

- Payments into national health and pension schemes

- Provision of infrastructure to local populations (housing, power supply, roads, water supply and sanitation, waste collection and processing ...)

- Provision of public access to some infrastructure specifically built for the mining and/or metallurgical activities

There is no database providing public access to this information, which could be partly compiled from annual reports of those companies providing a detailed country-level breakdown of their operating costs and reporting their social performance. Annual reports produced by mining companies mostly only provide data aggregated at corporate level. Private equity companies do not have to publish annual reports.

A detailed assessment on the socio-economic impacts of mining, providing somewhat more detailed data, is available for global gold mining over the 1990-2013 period (Maxwell Stamp PLC and The World Gold Council 2015). It provides data and analysis for the 30 largest gold-producing countries. It states that the industry provides one million direct employments worldwide, plus three million additional indirect employments in companies providing services and goods to the gold mining industry. In some poorer countries, with relatively limited development alternatives (Burkina Faso, Ghana, Guinea, Kyrgystan, Mali, Papua New Guinea, Suriname, Tanzania), gold mining generates more than $10 \%$ of the national gross value added, this representing more than the official development assistance received by some of these countries. However, these benefits are only temporary, as they will stop once ore reserves are mined out. Therefore, the transformation of this temporary bonanza into actions that can generate lasting benefits, for instance through investment into health and education, is of major importance. This requires a strong commitment to good governance by the political personnel and the administration of these countries.

\section{Towards global mineral and metal governance}

So far, most minerals and metals are globally traded commodities with prices reflecting supply and demand, as well as market anticipations of near-future supply and demand trends. The pricing is also dependent on the physical and chemical characteristics of the raw material. For instance, physical copper traded at the London Metal Exchange, one of the world largest trading places for minerals and metals, must meet wellspecified technical standards (LME 2020), and comparable requirements are existing for all traded minerals and metals. With the exception of the requirements set by the US DoddFranck Act and the EU Regulation 2017/821 laying down supply chain due diligence obligations for importers of gold, tantalum, tin or tungsten originating from conflict-affected and high-risk areas, there are no requirements regarding the environmental and social conditions under which specific minerals or metals were produced.

However:

- major financial scams such as the Bre-X mining scandal, happened in 1997 (Nicholls 1999);

- environmental disasters such as the OK Tedi copper-gold mine dumping of mine waste in PNG's Fly River (Marychurch and Stoianoff (2006), Zorn (2018));

- the repeated failure of tailing dams and their very visible impacts (Diehl 2020); and

- opposition to mining projects by local populations and/or some NGOS

have triggered changes, at least in some countries, in regulatory frameworks and corporate practices (IRP 2020). But, despite the efforts of some companies, a long way remains to see the development of a globally implemented competitiveness framework based on sustainable development principles and the key governance principles of transparency and full economic, environmental, governance and social performance reporting and accountability of companies and authorities.

In its scientific assessment of Mineral Resource Governance in the 21 st century (IRP 2020b), the UN International Resource Panel identified nearly 90 initiatives, most of them at global scale, aiming to foster better mineral and metal governance. While none fully addresses the four dimensions of sustainable development (economy, environment, governance and social or "quadruple bottomline"), three of them stand out as examples that could inspire broader global developments, possibly within the framework of the creation of the International Minerals and Metals Agency advocated here:

- The public reporting obligations for companies listed on their stock markets, according to specified national standards, of the data and information related to mineral exploration and mine development projects has been implemented in some countries, either by the stock market regulatory authority or by industry associations (CRIRSCO 2020). Such reporting obligations apply, for instance, to the over 1,100 companies listed on the Toronto (Canada) Stock Exchange (TSX and TSX-V codes) and to the over 600 companies listed on the Australian Stock Exchange (Code: ASX). The oldest (2001), and most widely used national reporting standard is the Canadian National Instrument NI 43-101 (Ontario Securities Commission 
2011). Public reporting according to the NI 43-101 standard is compulsory for the over 1,100 companies, many being junior exploration companies, listed on the Toronto Stock exchange (Codes: TSX and TSX-V). In Australia, the JORC reporting standard is compulsory for the over 600 companies listed on the Australian Stock Exchange (Code: ASX). Reporting codes are even voluntarily used by some companies that are not legally bound to use them, as a sign of their commitment to greater transparency and to foster trust in their activities.

NI 43-101 so far is the most advanced reporting standard on exploration and mine planning activities as it sets the most detailed reporting and publicity obligations among all the comparable national standards. While these national standards were designed to protect investors against the risk of being manipulated by false, manipulated or incomplete information from mining companies, their effective use, developed over the last two decades, provides to all stakeholders an unprecedented amount of data and information on an important percentage of the global mineral exploration and mine development projects. The data and information published by companies are accessible via public, free-of-charge portals such as sedar.com for companies listed in Canada and listcorp. com for companies listed in Australia.

Such standards do not impose any sort of environmental and social impact assessments of projects, or the preparation of detailed mine closure and site remediation plans. Such obligations are set by national or regional legal frameworks. However, the relevant data and findings will be available from these reports as they have an impact on a project economic parameters such as capital expenditure, operating costs, cash flows and the rate of return of the projects

- The development of sustainable performance reporting by companies. Since 1997, a non-Governmental Organisation, the Global Reporting Initiative (GRI, website: globalreporting.org), develops sustainability performance reporting guidelines (nowadays named standards) in collaboration with industry organisations. These guidelines/standards provide a detailed structure and help for companies voluntary to report their corporate economic, environmental and social performance.

In 2017, according to the GRI database, 216 companies voluntarily produced a sustainable development, or sustainable performance (the name of such reports is varying) report of some sort. Out of these, 115 were produced in compliant with either the version 4 of the GRI guidelines or the then recently released GRI Standards, which supersede the former guidelines. Although the GRI database identifies 28 companies from the People's Republic of China that produced some form of sustainable development report in 2017, none meets the GRI guidelines or standards requirements, and in most cases even the most basic information about the company's operations, such as revenue or staff size, is not provided.

Most reports, even when compliant with the GRI guidelines or standards, provide information and data consolidated at the company level. Data and information on individual operations, which would possibly be of high value to directly concerned stakeholders, is generally unavailable. The use of the GRI standards is entirely voluntary; there are no obligations so far set by stock markets or national authorities to mining companies to report their sustainability performance, an important shortcoming on the way to global sustainability.

What is nowadays an exception should be the norm, and this norm should be internationally defined and implemented.

- The reporting of payments made by oil and gas or mining companies to the authorities of the countries where they operate was cross-checked with the payments that those authorities declare having received. The launch of the Extractive Industries Transparency Initiative in 1995 is an important step towards the development of transparency of the economics of mineral and metal production, as it provides a standard for the reporting of legal frameworks and fiscal regimes, of contract and exploration/mining licence allocations and reporting an overview of exploration and mining activities, in addition to the payments made to the authorities by companies active in each participating country, and to the payments received by the authorities from companies active in the country. So far, 55 countries participate to the EITI, but the world's largest producers of minerals and metals (Australia, Brazil, Canada, China, India, the Russian Federation, the USA are not part of the initiative). The reporting of payments made to the countries where companies operate should become a systematic component of the quadruple bottom line sustainability reporting.

Despite the progress made towards transparency, much further efforts involving all stakeholders in a coordinated way remain to be done. Many companies and governments may object to such an elaborate framework of reporting obligations, and lobby against it. There is certainly a need to adapt the reporting obligations to the size of the individual operations to make them as manageable as possible. But quadruple bottom line sustainability reporting is needed in view of the unprecedented global sustainability challenges. It would be a formidable instrument, consistent with the United Nations Sustainable Development Goals, to foster trust among all stakeholders and to set a global level playfield for sustainable competitiveness.

Of course, these considerations are of equal importance for other industries, such as agro-industries, water supply, energy 
production, textile production and many more that have major impacts on sustainability.

The important pro-governance actions that happened over the last two decades have not killed the industry, by far. To the contrary, they help to build trust among stakeholders and provide more predictable frameworks for the massive investments that will be needed in the coming decades to provide the world with the minerals and metals it will need to meet the needs related to its burgeoning population, to the rapid growth of the global middle class and to the transition towards a low-carbon society based on mineral- and metal-intensive energy production from renewable sources (Christmann 2017; Hund et al. 2020).

However, the current lack of commitment by the Chinese authorities and companies to these initiatives is a major hindrance for the development of a global good governance framework. This undermines the development of the global pro-sustainability level playfield needed to see the industry progress faster towards the UN SDGs and distorts the global minerals and metals markets. The respective weights of China, the EU and the USA on minerals and markets, and the changes that happened over the 2002-2018 period, have been assessed by a detailed study of the German Raw Materials Agency (Perger 2020).

Industrial end-users and customers of mineral- and metalcontaining goods and services have the right to know the environmental and social conditions that prevailed for their production. Blockchain technologies can make the labelling of minerals and metals possible; standards and certification schemes are already widely used in the industry; thus, it is essentially a matter of commitment by governments and industry to foster the development of transparency, traceability and accountability.

The creation of an International Minerals and Metals Agency (IMMA), if well supported by the states and industry, could also be a very important move if it would be tasked and funded to:

- provide policy-relevant advice and support for the development of national/regional sustainable minerals and metals policies and regulations, and to their effective implementation;

- develop forward looking demand and supply scenarios that integrate all the dimensions of sustainable development;

- provide guidance to research and innovation;

- set policy-relevant guidelines and standards to report on new projects and on ongoing develop transparency and accountability and monitor/report on their implementation;

- develop ecolabelling of minerals and metals;

- document and disseminate existing best practice; and

- provide training and support to national/regional level data acquisition (geoscientific surveys, environmental baseline data) and for strengthening the national/regional institutions needed for an efficient and sustainable management of their mineral resources.

Its mandate could be inspired by the examples of other International Authorities and Agencies, such as the International Seabed Authority and the International Energy Agency and benefit from the experience of these organisations.

The G-20 appears as a possible framework to see an elaboration of such an idea, as its members represent, in value, $67 \%$ of the 2018 world production of non-fuel minerals (total value of the world production: 992 billions \$US, not including cement and other construction materials, nor gemstones, data source: Reichl and Schatz 2020). Several other institutions such as the European Commission, the OECD, the World Bank, industry organisations and NGOs should be part of the necessary conceptual work. Although terrestrial resources are managed by national regulations, much could be learned, from a sustainability perspective, from the over 20 years of experience of the International Seabed Agency in regulating deep-sea mineral resource exploration and mining in international waters.

Resources could come from a sustainable tax resources tax, levied by the authorities in charge of collecting taxes and levies from mining activities in participating countries. These authorities would then transfer the collected funds to IMMA. A $0.1 \%$ tax on the value of all minerals and metals produced would for instance generate nearly 1 billion $\$ /$ year, a resource that could be used to address the many needs, all over the world, including:

- geoscientific data acquisition processing and dissemination needed to locate the mostly deeper seated, hidden, mineral concentrations that will be needed to secure the growing future minerals and metals;

- sustainable mineral and metal production and use related education;

- research and innovation to develop innovative prosustainability exploration mining ore processing and metallurgical technologies as well as technologies, techniques and training in support of pro-circularity actions (energy and water use reduction, emissions and solid waste minimisation, LCA/MFA, eco-design, maintenance, refurbishing, re-manufacturing, re-use and recycling, including the re-use and reprocessing of mining waste);

- institutional strengthening and capacity building, with a particular focus on developing countries; and

- development and sharing of best practice and standards.

The action should include the creation and stable funding of an international competence pool, to provide technical and legal support to those states not having enough human and/or material resources to run sectoral institutions that 
governments need to manage, regulate and promote their minerals and metals industry (essentially a Geological Survey, a Mining Department and an Environmental Departments).

This tax would have a very tiny impact on manufacturing costs, and even less on the cost of products and services as for most of them the cost of minerals and metals is only a small part of their market prices ( 1 to $2 €$ for a smartphone, 2,000 to $3,000 €$ for an average car); the impact on the price to be paid by customers would be negligible but the positive impact on sustainable impact could be major!

Such a multilateral development could play a major role in creating a new level-playfield for the minerals and metals industry, and commensurate to the global challenging problems that humanity is confronted with, of which global warming is just one. It could be very instrumental in defusing the tensions that may otherwise develop in a global context of (re)rising nationalisms and communitarianisms that could well exacerbate and derail in a major global conflict fuelled by an unregulated competition among nations wanting to secure raw material supplies needed for their economic development and/or as powerful strategic geopolitical tool.

\section{A sustainable European Union in the global context}

The European Union is one of the world largest end-users of minerals and metals, due to its extensive physical infrastructure and the material-intensive lifestyles of its citizens. Unfortunately, trade statistics do not allow to trace real mineral and metal consumption by any state, as minerals and metals that are embedded in traded goods are not statistically recorded.

The internationally used nomenclature for traded goods (Harmonized Commodity Description and Coding Systems) described, for instance, by the United Nations Trade Statistics knowledge base (https://unstats.un.org/unsd/tradekb/ Knowledgebase/50018/Harmonized-CommodityDescription-and-Coding-Systems-HS), implemented by national customs, measures trade flows in great detail. But it does not, and cannot, provide information on the minerals and metals contained in many of the traded goods such as ore concentrates, alloys and scraps (these are statistically recorded as traded tonnages, but not their metal contents) or end-user products such as cars, laptops, smartphones, windmills and the thousands of traded product categories. Thus, only Direct Materials Consumption $(\mathrm{DMC}=$ National production + Imports - Exports) of statistically identified minerals and metals are statistically well documented.

EUROSTAT, the EU statistical office, provides Direct Material Consumption Statistics (EUROSTAT 2020) shown in Fig. 5.

From this diagram, one may wrongly infer that Europe's mineral and metal consumption, and the related environmental footprint, is on the decline and that, after all, mineral- and metal-related issues may become of less importance as the European economy "dematerialises" (in other terms less resources are used per unit of GDP). But this is only one part of the story.

EUROSTAT trade statistics also provide the value of imports and exports of goods into the Eurozone, which counts 19 EU Member States. It shows a very rapid growth of imports of goods from China over the 2002-2019 period. In value, they grew from about 63 billion nominal \$US in 2002, to about 298 billion nominal \$US in 2019, a $473 \%$ rise in just 17 years. Over the years, China has become the main source of EU imports of goods, the USA being a distant second with 214 billion \$US of exports to the Eurozone in 2019. Many of these imports contain statistically unrecorded minerals contained in the imported goods. In 2019, $19 \%$ of all goods imported to the EU came from China. The EU is also heavily dependent on imports from beyond its borders, essentially from China, for most of the minerals and metals it deems critical for its economy (Vidal-Legaz et al. 2018; Blengini et al. 2020). This dependence has several causes:

- The European geology is limiting the possibilities to discover significant deposits of some minerals and metals such as borates, graphite, platinum group metals, phosphate, niobium, tin and tantalum ores, all of them being listed as raw metals critical to the EU in 2020.

- The insufficient exploration effort in EU countries was endowed with good mineral potential. The distribution of mineralisation potential throughout Europe is well documented.

The result of this is an important, yet undocumented, environmental footprint of the EU outside of its borders, and a high dependence on mineral imports, in many cases from China due to that country's dominant role in the world production of many minerals and metals (Fig. 4) and its importance as the key global manufacturing hub. Due to the dominance of coal in China's energy mix (58\% of the total energy consumption in 2019 according to bp (2020)), the EU environmental footprint is far worse than what is documented by considering only its Direct Material Consumption. In addition, the EU and its Member States are also heavily exposed to supply risks in case one of the several latent conflicts involving China and its neighbouring countries, or the USA, turns into a fully fledged conflict. However, China may have limited interest in using its market dominance to use minerals and metals as economic weapons as it is itself heavily dependent on mineral and metal imports from other countries. Its geology, its economic needs and its heavy dependence on coal as its main energy source compel China to rely on massive imports of coal as well as of bauxite, copper, cobalt, iron, lithium, manganese, nickel and platinum group elements. Thus, the 
Development of resource productivity in comparison with GDP and DMC, EU-27, 2000-2019

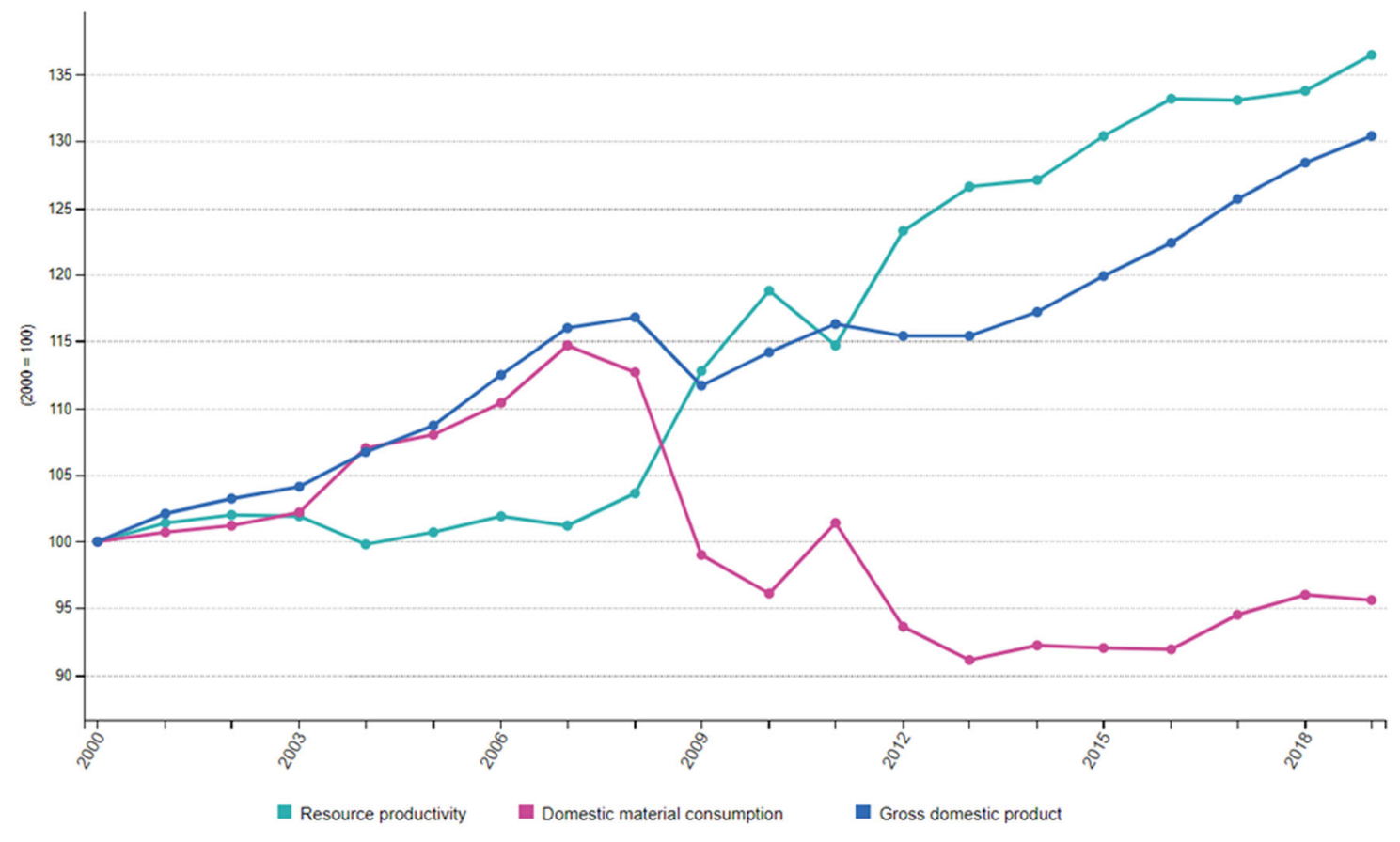

Note: GDP in chain-linked volumes, reference year 2010.

Source: Eurostat (online data code: nama_10_gdp: env_ac_mfa: env_ac rp)

Alurnstat re

Fig. 5 EU-27 Direct Material Consumption 2000-2019 in basis points (basis 100 in 2000), GDP growth and inferred resource productivity. Source: EUROSTAT (https://ec.europa.eu/eurostat/statistics-explained/ index.php/Material_flow_accounts_and_resource_productivity\#: :text=

development of a stable, sustainable, level international playfield should be in the very interest of China's authorities.

According to the 2020 edition of the European Commission's Critical Raw Materials assessment (Blengini et al. 2020), 29 mineral raw materials are deemed critical to the EU economy. The EU import reliance is $80 \%$ or more for antimony, bauxite, cobalt, indium, lithium, magnesite, magnesium, molybdenum, natural graphite, phosphate rock, platinum group metals, rare earth elements, scandium, tantalum, titanium and zirconium. Estimates for import reliance are unavailable for tungsten and vanadium. Occurrences, and even deposits of some of these minerals, are known in Europe, as documented by the PROMINE geographic web portal (http:// www.europe-geology.eu/promine/), but many remain undeveloped for economic reasons and/or opposition by some local communities to exploration and mining activities.

Mining and exploration remain active in some European countries, essentially Finland, Portugal and Sweden. However, the amount of investment made in mineral exploration and mining remains modest. According to S\&P Global, a leading commercial mineral intelligence provider, in 2017, the EU attracted about $5 \%$ of the global mineral exploration made in that year (S\&P Global 2018), equivalent to about US\$ 420 million, or about $94 \$ \mathrm{US} / \mathrm{km}^{2}$, which is more than the USA (68 US\$ $/ \mathrm{km}^{2}$ ) and a bit less than Canada $\left(118 \$ / \mathrm{km}^{2}\right)$.
Estonia\%20and\%20Sweden.-,The\%20EU's\%20domestic\%20material\% 20 consumption $\% 20$ compared $\% 20$ with $\% 20$ the $\% 20$ world's $\%$ 20material,this\%20is\%20above $\% 20$ world $\% 20$ average)

However, investments in EU mineral exploration are very unequally distributed. In 2018, only Finland and Sweden attracted over $50 \mathrm{M} \$ \mathrm{US}$, while several EU Member States (Austria, the Czech Republic, France, Germany, Greece, Poland, Slovakia, UK) only get less than 10 M\$US (S\&P Global 2019), although they are geologically well endowed with mineral resources, as documented by the ProMine online EU mineral resources map (EuroGeosurveys 2021).

This underinvestment has several causes, one of them being the very low public acceptance of mineral exploration and mining activities, despite the high dependence on imports and the massive mineral and metal use necessary to sustain the European lifestyle, including the lifestyle of those citizens that vocally, and sometimes violently, oppose to mineral exploration and mining activities. Opposition to exploration and mining is such in some parts of the EU that politicians are frightened to allow these activities, as there is much potential for the development of conflicts in the concerned areas.

EU also still has some significant metallurgical capacities, including for non-ferrous metals, the existence of metallurgical know-how and of smelters/metal refineries being a major asset for the development of metals recycling, which supports the circularisation of the EU economy. Metal recycling in the EU is quite advanced, as documented by the 2018 edition of the EU Raw Materials Scoreboard, but for many rare metals of 
importance for instance for the electronics or the renewable energies industries recycling rates of metals from end-of-life products remain very low $(<10 \%)$. There still are challenging behavioural, capacities, policy, technological and economic obstacles to overcome to see significant progress; these challenges having been described in detail by the International Resource Panel (IRP 2013b). The presence of base metal smelters in the EU also contributes to the supply of the EU economy with several rare metals that can only be obtained as by-products of metallurgical/refining processes, such as indium (zinc metallurgy), selenium or tellurium (copper metallurgy) and rhenium (molybdenum metallurgy).

In the European Union, legal competences, either devolved to the Union or shared between the Union and its Member States, are defined by the Treaty on European Union (currently the Lisbon Treaty, entered into force on January 1, 2018 (European Union 2020)). Where the Union has legal competences, it can develop and adopt regulations and directives that are legally above national laws. In this context, the development and implementation of specific mineral and metal policies as well as the development of the laws and regulations applicable to mining remain national, or in some EU Member States, regional legal competences. An overview of some individual EU Member States policies on minerals and metals, together with those of other G-20 Member States, was published by Hilpert and Mildner (2013).

However, the EU has exclusive legal competences in the following domains, to mention only those that indirectly relate to mineral and metal production or trade:

- Competition rules related to the interior market

- Conservation of marine biological resources related to fisheries

- Trade

In addition, it has shared competences in the following domains:

- Economic, social and territorial cohesion

- Environment,

- Energy,

- Research, technological development and space

- Development cooperation and humanitarian aid

In absence of an overarching EU minerals and metals policy, this complex policy and regulatory framework can lead to contradicting, and even conflicting, decisions that are obstacles on the way to a more stable and sustainable raw materials supply to the EU economy.

For many years, the European Union actions related to minerals were limited to development cooperation and some limited research efforts.
In the development cooperation framework, SYSMIN, a stabilisation mechanism providing EU support funding to States dependent on minerals exports, part of the Africa, Caribbean and Pacific (ACP) group of States, was introduced in 1979, in the Lomé II Convention. EU support was conditioned by the occurrence of an unforeseeable event putting mineral exports from countries highly dependent on these exports. In its last tranche, from 1995 to 2000 , SYSMIN had a 575 M€ budget, and during the SYSMIN lifetime about 20 ACP countries benefited from its support, for the funding of actions needed to strengthen/diversify their mining industry and/or to strengthen the institutions needed to regulate and promote mineral exploration and mining activities (such as Geological Surveys, Mining Directorates and Environmental Agencies). In the case where mining activities were found, further to expert analysis, lacking of realistic economic perspectives, SYSMIN funds were used to support diversification actions in other sectors of the economy. SYSMIN was discontinued in 2000 without a public evaluation establishing its successes and failures of this unique financing facility. The disregard for minerals and metals in the EU development policy is a case of strategic myopia, detrimental to both the developing countries and to the EU's long-term interests.

In parallel to SYSMIN, addition technical support projects were funded out of the various tranches of the European Development Fund, but here too the funding in support of this important economic sector in many developing countries came to a halt at the end of the 8th European Development Fund (EDF), in 2000.

Currently, EU-ACP cooperation related to the mineral resources has resumed somewhat, at a rather modest level, with three important projects:

- The ACP-EU Development Minerals Programme (2015$2018)^{1}$, in partnership with the UN Development Programme (UNDP). The capacity-building programme was focused on supporting the development of the ACP development minerals sector (essentially construction materials) to foster the development of local enterprises.

- The PanAfGeo project (2016-2019) ${ }^{2}$, a capacity-building project to support Africa's Geological Surveys, in partnership with EuroGeoSurveys, the Association of European Geological Surveys,

- The EU-Pacific Community partnership on Deep-Sea Minerals (2011-2016) ${ }^{3}$ to improve the governance and management of the deep-sea mineral resources of 15 Pacific Island countries.

\footnotetext{
${ }^{1}$ Website : http://developmentminerals.org/index.php/en/

${ }^{2}$ Website : http://panafgeo.eurogeosurveys.org/

${ }^{3}$ Website : https://dsm.gsd.spc.int/
} 
While up to 2000 SYSMIN and European Development Fund support had a major and still lasting positive impact on the economy of a number of developing countries such as Ghana, Guinea, the Dominican Republic, Papua New Guinea, Senegal and Zambia, no EU programme has replaced the support it provided in supporting economic activities, and their supporting regulatory institutions, although these activities are important, and in some cases vital, to these economies.

From 2000 to 2008, while China's economy entered in a very rapid economic development phase, of a magnitude unknown in human history, rapidly becoming the world largest producer of many minerals and metals, the European Union paid little attention to these critical resources. The then prevailing mantra was to support the development of free trade, assuming that this would suffice to see its economies being able to secure the supplies of the minerals and metals they needed. This has a number of severe consequences for the EU economy, who now faces rising difficulties to supply its economy with the long list of minerals and metals it deems as critical (Blengini et al. 2020).

An important turning point was the G-8 Heiligendamm Summit, organised in 2007 by Germany. Its final declaration (G8 2007) includes a full section (articles 60 to 87, included) titled: "Responsibility for Raw Materials: Transparency and Sustainable Growth", stating "Raw materials produced by the extractive sector are a key factor for sustainable growth in industrialised, emerging and developing economies", and outlining a number of issues where action was needed.

One year afterwards, the European Union agreed on the launch by the European Commission of the Raw Materials Initiative (European Commission 2008). Within the limits of the European Union actions possible in relation to mineraland metal-related policy making, this is an important milestone, as this initiative is still in progress nowadays and will be continued as part of the current European Commission's agenda, as detailed below.

The Raw Materials Initiative is developed around three pillars:

- Ensure access to raw materials from international markets under the same conditions as other industrial competitors

- Set the right framework conditions within the EU in order to foster sustainable supply of raw materials from European sources

- Boost overall resource efficiency and promote recycling to reduce the EU's consumption of primary raw materials and decrease the relative import dependence

For some reasons that will not be elaborated on here, the Raw Materials Initiative also addresses natural rubber and wood in addition to minerals and metals.

It follows an earlier attempt by the European Union to address its dependence on mineral and metal imports as well as the related risks (European Commission 1975), which soon faded into political oblivion although the conclusions of that Communication are, unfortunately, still valid:

We must not allow the complexity and gravity of the problems of the moment to cause us to lose sight of the other problems we shall have to face in the future. Rather should we let them make us aware of how adequate preparation can at least facilitate the solution of such problems if not make it possible to forestall them. In short, it must be recognized that the scale of this problem is too great for individual Member States; and its importance demands the establishment of that point of cohesion, currently lacking, for all the different projects and initiatives underway here and there throughout the Community in this enormous field.

Forty-five years after its publication, the analysis presented in this Communication remains largely valid. Despite the complexity of developing an EU-wide consensus on mineral raw material issues among 27 Member States with very different understanding and approaches to the issues, important progress has been made. As part of the implementation of the Raw Materials Initiative, the European Union invested about 1 billion $€$ in actions to support the Initiative over the 2014 2020 period, mostly in Higher Education, EU-level Coordination Actions, Research and Innovation projects within the framework of its 2014-2020 Research and Innovation Framework Programme, Horizon 2020. Some of these Coordination Actions are focused on developing an international dialogue on mineral raw material-related issues between the European Union and the rest of the world (within the framework of projects such as the "World Forum on Raw Materials (FORAM) ${ }^{4}$, and the International Round Table on Materials Criticality in Business Practice, IRTC ${ }^{5}$ ). To the European taxpayer unfamiliar with the minerals and metals industry and supply chains, and the related issues, one billion $€$ certainly appears as a major effort, but it is merely equivalent to the capital expenditure needed to commission two new medium-sized mines, the largest mines requiring several billion $€$ in capital investment before actually producing the first ton of a mineral raw material. A single pilot scale test of a new large-scale process or material may cost up to 150 million $€$, depending on the equipment that will be needed and on the duration/complexity of the pilot test, which may involve complex certification activities, for instance, if it relates with applications in the aeronautics, defence, health or space industries.

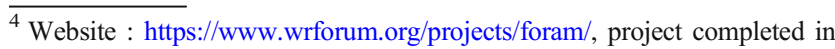
2018

${ }^{5}$ Website : https://irtc.info/, project launched in in 2018, ongoing
} 
For the first time ever, the Commission also established a joint piloting of the programming of the research activities associating EU industries as well as research institutes within the framework of the European Innovation Partnership on Raw Materials (EIP-RM) launched in 2012 (European Commission 2012). The EIP developed a wide-ranging Strategic Implementation Plan (SIP, EIP-RM 2013a, b) with 95 proposed concrete actions, structured into 7 priority areas and 24 action areas. The SIP was then used by the European Commission and the Member States to elaborate the raw material-related parts of the subsequent annual Horizon 2020 Work Programmes.

In addition to this important, but still insufficient, European research and innovation effort, EU Member States were encouraged and supported by EU co-funding to develop coordinated programming of a part their national research and innovation programmes related to mineral and metal raw materials thanks to the development of a common research agenda (Vidal et al. 2013) and of joint call for research and innovation project proposals, through the ERA-MIN programme, launched in 2011 (still ongoing, entering its 3rd phase in 2021).

In parallel, the EU minerals and metals industry, its umbrella organisations, the European Geological Surveys, academia and research institutions joined efforts and developed their research and technological development roadmap within the framework of the European Technology Platform on Sustainable Mineral Resources (ETP-SMR 2015) and the Horizon 2020 co-funded VERAM ${ }^{6}$ coordination action, the latter being the most recent research agenda, based on a 2050 vision of the issues and the needs (Elvnert et al. 2018).

Another major development related to the Raw Materials Initiative, complementary to the Horizon 2020 project-based actions, was the creation, in 2015, of the EIT Raw Materials ${ }^{7}$, the world largest mineral- and metal-related formal knowledge and innovation community, co-funded by the European Union. In 2020, it links about 120 partners from industry, academia and research and over 190 project partners, the world largest education, research and innovation ecosystem related to minerals and metals.

In addition to tangible innovation outcomes, a major output of this European research and innovation effort is the development of strong synergies and co-operations among the members of the precedingly highly fragmented and uncoordinated European mineral raw material research community. Another important result for the future, in addition to the knowledge and the new products, technologies and services developed thanks to the effort, is the renewed interest of much needed young talents all over the EU for raw mineral- and metal-related research and innovation activities, which was for too long unduly perceived as a domain of the past.
The development of this Pan-European research and innovation ecosystem is a major foundation stone in support of the future EU competitiveness and sustainability, especially if Europe manages to pool its resources to develop globally innovative and competitive products in domains where there is a high probability of massive future global demand, for instance in low-carbon energy production and storage solutions or lowcarbon transport solutions. The launch, by the European Union, of the European Battery Alliance $(2017)^{8}$ is an important step in this direction.

But, to the contrary of China whose government has developed rapid vertical supply chain integration, from secure mineral resource supplies to the end-product, in key industrial sectors such as aeronautics, electromobility or energy production from renewable sources, the Raw Materials Initiative has still a long way to go to meet two of its above-stated objectives:

- Ensure access to raw materials from international markets under the same conditions as other industrial competitors

- Set the right framework conditions within the EU in order to foster sustainable supply of raw materials from European sources

China still has a number of advantages, including its population of 1.4 billion people, and the unfaltering prioritisation of higher education and research by its leadership and recognition of minerals and metals and their related downstream applications as strategic to China's future.

Since the early 2000s, China is leading, on its terms, the international competition for access to many of the minerals and metals that the EU will need to develop its future industrial champions and, to the contrary of China, and to some extent to Japan, the EU has not yet put in place a mechanism allowing a public-private co-funding mechanism to fund the exploration and mine development projects within the EU borders and abroad that would be needed to secure EUbased mineral- and metal-dependent industrial production.

Under the 2021-2027 Financial Framework, the EU's multiannual budget for the coming years, the European Development Fund has disappeared, its resources being merged in the much broader Neighbourhood, Development and International Cooperation Instrument (NDICI, European Commission 2018). One of its priorities is "Promoting fair, sustainable and undistorted access to extractive sectors". Early March 2021, the final version NDICI was not yet published.

For the time being, as documented by the recently released 4th assessment of the raw materials critical to the EU economy (Blengini et al. 2020), the EU remains as dependent as it was in 2008, at the launch of the Raw Materials Initiative, on the

\footnotetext{
${ }^{8}$ Website : https://www.eba250.com/, ongoing since 2017
}

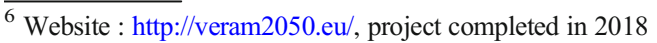

${ }^{7}$ Website : https://eitrawmaterials.eu/, ongoing since 2015.
} 
imports from beyond its borders of many of the minerals and metals its economy needs.

It is likely to need even more imports in the future, as the EU seeks to become again an innovative and competitive industrial hub in specific, clearly identified sectors such as:

- the production of energy from low-carbon, but mineraland metal-intensive sources (Hund et al. 2020) or

- the development and production of batteries at the heart of future cleaner electro-mobility and a critical component for the successful deployment of energy production systems relying on renewable, but intermittent energy sources such as sunshine or wind.

The importance of the mineral raw material issues for the European Union's future is further highlighted by the evergrowing list of minerals the EU considers critical to its economy. While in 2010, in the first assessment of the raw materials critical to the EU economy (European Commission 2010a, 2010b) 14 minerals and metals were found as critical, this number grew through continuously through the successive (2014 and 2017) editions of the assessment, to reach 30 in the fourth assessment, released in September 2020 (European Commission 2020).

The EU Raw Materials Information System (EU-RMIS ${ }^{9}$ ) is a web portal providing structured access to detailed information on the numerous specific actions, projects and reports that were produced either by the European Commission Services or by the different organisations involved in the implementation of the EU Raw Materials Initiative.

\section{Conclusions}

The EU, and its Member States, have to take complex coordinated decisions, with important international implications, regarding the future of the EU economy, continuing its long history of being one of the world's most innovation-led regions. To be consistent with its Circular Economy Action Plan, and to address the sustainability issues outlined in this paper and in numerous publications worldwide, it needs to:

- act on developing a more circular economy, to reduce its demand for primary minerals and metals (those coming from mines, secondary minerals and metals are those gained from recycling);

- work jointly to develop the access to Europe's own geological potential, which will need to address significant opposition by some stakeholders. This is needed as procircularity actions can only somewhat reduce the need for primary resources;

\footnotetext{
${ }^{9}$ Website : https://rmis.jrc.ec.europa.eu/
}

- invest in the development of a public 3D data infrastructure documenting the EU subsurface and its resources, including mineral resources, groundwater and geothermal energy sources (a clean, renewable and dependable energy source). This is needed to guide the search for some of the resources that the EU will need in the future. IT also is an important management tool. Compared to the multibillion public investments in developing EU space technologies and knowledge, the effort in developing EU's knowledge of its own subsurface remains appears negligible, being essentially limited to the variable, but mostly very limited, efforts of individual Member States. So far, the very modest public investment is limited to the panEU harmonisation of existing data and knowledge, the scope of the current European Geological Data Infrastructure project (EGDI 2021) implemented by EuroGeoSurveys, the Association of the European Geological Surveys and its members. The effort needs to be recognised as a component of Europe's scientific infrastructure, widened in scope, and endowed with significantly larger resources to acquire the geophysical and geological data necessary to develop a 3D model of Europe's subsurface and of its resource to a depth of $1000 \mathrm{~m}$, with a focus on high-potential areas for geothermal resources, and/or groundwater, and/or mineral resources;

- reduce its dependence on imports from outside its borders and ensure that imported raw materials, as well as the products derived therefrom, meet the same environmental and social standards than those produced within the EU, in particular with respect to climate targets;

- develop internal taxation harmonisation in line with the objectives of the OECD/G20 Inclusive Framework on (Taxation) Base Erosion and Profit Shifting (OECD 2021), bringing an end to the existence of EU's double standards in defining tax heavens, whereby in the absence of EU-wide taxation harmonisation, Member States can provide legal frameworks (Alvarez-Martínez et al. 2018; Lane 2020; European Parliament 2021) that allow multinational companies to organise large-scale taxation base erosion and profit shifting, while these Member States avoid being listed on the EU list of tax heavens;

- enhance its investment in mineral-, metal- and innovative material-related research and innovation. To meet the challenges the EU is confronted with and remain the world's largest economy higher education, research and innovation efforts need to be further ramped up. While the 1 billion $€$ research and innovation co-funding invested by the EU over the 2014-2020 period may for some reader appear as a huge investment, this boils down to each EU citizen investing only about $0.3 € /$ year in research and innovation in a domain that will considerably shape EU's future competitiveness and well-being; 
Table 1 European Raw Materials Action Plan (outline) for the 2020-2027 period. Source: European Commission 2020

Action

1 Establishment a European Raw Materials Alliance, initially to build resilience and open strategic autonomy for the rare earths and 2020-2027 magnets value chain, before extending to other raw material areas

2 Develop sustainable financing criteria for the mining, extractive and processing sectors by the end of 2021

3 Launch critical raw materials research and innovation in 2021 on waste processing, advanced materials and substitution

Map the potential of secondary critical raw materials from EU stocks and wastes to identify viable recovery projects by 2022.2022

5 Identify mining and processing projects and investment needs and related financing opportunities for critical raw materials in the EU 2025 that can be operational by 2025 , with priority for coal-mining regions

6 Develop expertise and skills in mining, extraction and processing technologies, as part of a balanced transition strategy in regions in 2021-2027 transition from 2022 onwards (Commission, industry, trade unions, Member States and regions)

7 Deploy Earth-observation programmes and remote sensing for resource exploration, operations and post-closure environmental 2021-2027 management (Commission, industry)

8 Develop Horizon Europe R\&I projects on processes for exploitation and processing of critical raw materials to reduce environmental 2021-2027 impacts starting in 2021

9 Develop strategic international partnerships and associated funding to secure a diversified and sustainable supply of critical raw materials, including through undistorted trade and investment conditions, starting with pilot partnerships with Canada, interested countries in Africa and the EU's neighbourhood in 2021.

10 Promote responsible mining practices for critical raw materials through the EU regulatory framework (proposals in 2020-2021) and 2020-2027 relevant international cooperation32 (Commission, Member States, industry, civil society organisations)

- act on the international scene, possibly within the framework of the UN Environment Assembly (UNEA) and of the UN Environment Programme to promote the development of the global mineral and metal governance framework called for in this paper and in the UN International Resource Panel Report on Mineral Resources Governance in the 21st century (IRP 2020) and contribute to the creation of the International Minerals and Metals Agency; and

- support capacity building and institutional strengthening related to mineral and metal production in developing countries, and foster their research and innovation activities, to support added-value development in these economies.

The economic weight and the values at the core of the European construction could make it possible for the European Union to become a global game changer, rebasing the definition of competitiveness on a full and transparent integration of the four dimensions of sustainable development (Fig. 1). It is a challenge, and it may take years to overcome all the obstacles on the way. But what are the alternatives, and what could they mean for the continuation of the European Union construction?

In September 2020, the new European Action Plan on Raw Materials has been officially published (European Commission 2020), titled "Critical Raw Materials Resilience: Charting a Path towards greater Security and Sustainability".

It includes 10 action points (Table 1) that are well focused on a number of issues outlined in this paper.

The minerals and metals industry is a complex industry where actions mostly take 10 to 20 years to demonstrate success or failure, with numerous risks specific to this very particular branch of the economy (EY 2020). The sustainable production of minerals and metals is not an end, but a condition to feed specific industrial supply chain. Therefore, the success of the action plan will be conditioned by clearly and well-defined economic priorities. What are the industrial sectors where the European Union through a consensus of its 27 Member States (after Brexit) that the Union defines as priority sectors for its future economic and social development?

The development of the Battery Alliance, involving about 400 partners from all over the European Union, is a first reply to this strategic question of vital importance for the Union's future and the first European example of a vertically integrative action that addresses the full supply chain, from mining to the end-user product. As the EU political construction is deeply imprinted by the prioritisation of open market and free trade development, vertical integration was for a long time a no-go area in EU policy making. Another important step is the launch, in September 2020, of the EU Raw Materials Alliance (ERMA) ${ }^{10}$.

Addressing the global and the European sustainability issues outlined here requires EU-wide coherent long-term political visions and hard long-term work to develop international consensus, well beyond the ordinary political agendas. The vision, the consensus and the strategy to turn the vision into actions and results that benefit all, including outside the EU borders, will need to survive frequent elections and changes in political personnel as well as resistance to change by multiple stakeholders. No small challenge, in a period of flourishing conspiracy theories driving some political agencies and a

\footnotetext{
${ }^{10}$ Website : https://erma.eu/
} 
belief by some citizens that the circulation of profanities on social networks is all that is needed to understand the complexity of the modern world and address its daunting challenges. The European Commission, as a very stable institution not being exposed to the consequences of frequent electoral processes, appears as a major asset to build and coordinate the implementation of the needed long-term minerals and metals strategy the EU needs.

But, whatever the progress that can and will be made in EU mineral- and metal-related policies, much depends on the future actions of China's government and of the companies it directly or indirectly controls via its banking system and its sectoral policies (energy, environmental, research and trade policies). China is the world largest producer of over $30 \mathrm{~min}-$ erals and metals (Reichl and Schatz 2020). This makes China's support to:

- the development and effective implementation of transparent, verifiable, economic, environmental, governance and social international reporting standards on exploration and mineral/metal production activities is of major importance to the development of a sustainable global playing field for the 21 st century, and

- the creation and the development of the IMMA

of major importance to the future global supply of minerals and metals to the world economy and to the maximisation of the contribution of the industry to the UN Sustainable Development Goals, and beyond of a more sustainable and peaceful world.

It provides China with the opportunity of becoming one of the global benevolent economic and political leaders the world needs to address and overcome the threatening sustainability issues, of which climate change is just one, that may lead humanity to doom.

\section{Availability of data and material $\mathrm{XXX}$}

Code availability Not applicable

Author contribution Not applicable

Funding Not applicable

\section{Declarations}

Ethics approval Not applicable

Consent to participate Not applicable

Consent for publication Not applicable

Competing interests The author declares no competing interests.

\section{References}

Alvarez-Martínez MT, Barrios S, D'Andria D, Gesualdo M, Nicodème G, Pycroft J (2018) How large is the corporate tax base erosion and profit shifting? A General Equilibrium Approach. CESifo Working Paper Series 6870, CESifo

Australian Government (2016) Preventing acid and metalliferous drainage. In: Leading Practice Sustainable Development rogram for the Mining Industry. Report, 221 p.. The Australian Government, Canberra, Australia

Barbier E (1987) The concept of sustainable economic development. Environmental Conservation 14(2):101-110. https://doi.org/10. 1017/S0376892900011449

Blengini GA, El Latunussa C, Eynard U, Torres de Matos C, Wittmer D, Georgitzikis K, Pavel C, Carrara S, Mancini L, Unguru M, Blagoeva D, Mathieux F, Pennington D (2020) Study on the EU's list of Critical Raw Materials. In: Final Report, 157 p. JRC, European Commission DG https://rmis.jrc.ec.europa.eu/uploads/CRM 2020_Report_Final.pdf

Bp (2020) bp statistical review of world energy. Online database: https:// www.bp.com/en/global/corporate/energy-economics/statisticalreview-of-world-energy.html

Brown O. and Peduzzi, P. (2019). Driven to extraction: can sand mining be sustainable?. Online article. Hoffmann Centre, Chatham House (U.K.). https://hoffmanncentre.chathamhouse.org/article/driven-toextraction-can-sand-mining-be-sustainable/.

Christmann P (2017) Towards a More Equitable Use of Mineral Resources. In: Towards a more equitable use of mineral resources - natural resources research. https://doi.org/10.1007/s11053-0179343-6

Columbia Center on Sustainable Investment, United Nations Development Programme, United Nations Sustainable Development Solutions Network, World Economic Forum (2016) Mapping mining to the sustainable development goals: an atlas . (2016). White Paper, 77 pages - http://www.undp.org/content/ undp/en/home/librarypage/poverty-reduction/mapping-mining-tothe-sdgs $\% 2 \mathrm{D} \% 2$ Dan-atlas.html

Committee for Mineral Reserves International Reporting Standards (CRIRSCO) (2020). National reporting standards. Website: http:// www.crirsco.com/national.asp

Copper Fox Metals (2020) Company website: https://www. copperfoxmetals.com/projects/schaft-creek-project/overview/. Accessed on 2020/08/25

Darton Commodities Limited (2020) Cobalt market review 2019-2020 www.dartoncommodities.co.uk

Diehl P (2020) Chronology of major tailings dam failures - the Wise Uranium Project database on major tailings dam failures - http:// www.wise-uranium.org/mdaf.html

Downs TJ, Roa AC, Dixon KC, Duff P, Pasay E, Silverfine H (2020) The case for integrative sustainable development practice based on the Minas Conga gold-mining experience in Peru. Journal of Geoscience and Environment Protection 8:17-40. https://doi.org/ $10.4236 /$ gep. 2020.85002

EGDI (2021) European Geological Data Infrastructure project. [online] Available at: http://www.europe-geology.eu/ [Accessed 8 Mar. 2021].

EIP-RM (European Innovation Partnership on Raw Materials) (2013a) Strategic implementation plan part 1: defining priority areas and specific actions . European Commission, DG Enterprise (Brussels, Belgium) - https://ec.europa.eu/growth/sites/growth/files/eip-sippart-1.pdf

EIP-RM (European Innovation Partnership on Raw Materials) (2013b) Strategic implementation plan part 2: priority areas, action areas and actions. European Commission, DG Enterprise (Brussels, Belgium) - https://ec.europa.eu/growth/sites/growth/files/eip-sip-part-2.pdf 
Elshkaki A, Graedel T, Ciacci L, Reck BK (2018) Resource Demand Scenarios for the Major Metals - Environ. Sci Technol 52(5): 2491-2497. https://doi.org/10.1021/acs.est.7b0515

Elvnert J, Hyrkkö H, Mattos T, Hebestreit C, Wall P, Pool H, AgyemanBudu E, Mendes M, Nelen D, Mayer S, Ferrari A, Dall'Oro L, Tittarelli F, Mobili A, Mäki R, Wilhelmsson L Kinos T (2018) VERAM Research and Innovation Roadmap 2050 - Report, 52 p. European Union Horizon 2020 VERAM Project final document $\mathrm{http} / /$ veram2050.eu/just-released-research-and-innovationroadmap-2050/

Ericsson M, Löf O (2019) Mining's contribution to national economies between 1996 and 2016. Mineral Economics 32(2):223-250

ETP-SMR (European Technology Platform on Sustainable Mineral Resources) (2015) ETP SMR Strategic Research and Innovation Agenda - Report 40. http:/www.etpsmr.org/wp-content/uploads/ 2015/02/ETP-SMR-Agenda-A4-HD.pdf

EUROSTAT. (2020). Development of resource productivity in comparison with GDP and DMC, EU-27, 2000-2019

EuroGeosurveys (2021) ProMine Data Products - EGDI. [online] Available at: http://www.europe-geology.eu/promine/ [Accessed 26 Feb. 2021].

European Commission (1975) Communication on the security of the Community's raw materials supply - $\operatorname{COM}(75) 50$ - European Commission (Brussels, Belgium). http://aei.pitt.edu/51762/1/ A10574.pdf

European Commission (2008) The raw materials initiative - meeting our critical needs for growth and jobs in Europe - COM(2008)699 - http://eur-lex.europa.eu/LexUriServ/LexUriServ.do?uri=COM: 2008:0699:FIN:en:PDF

European Commission (2010) Critical raw materials for the EU European Commission, DG Enterprise (Brussels, Belgium) - as available for download from http://ec.europa.eu/enterprise/policies/ raw-materials/files/docs/report-b_en.pdf - Annex V: http://ec. europa.eu/enterprise/policies/raw-materials/files/docs/annex-v-b_ en.pdf

European Commission (2012) Making raw materials available for Europe's future wellbeing, Proposal for a European Innovation Partnership on Raw Materials. Communication from the Commission to the European Parliament, the Council, the European Economic and Social Committee and the Committee of the Regions. [COM (2012) 082]

European Commission (2013a) Best available techniques (BAT) reference document for iron and steel production - reference document, 627 p. - http://eippcb.jrc.ec.europa.eu/reference/BREF/IS Adopted_03_2012.pdf

European Commission (2013b) Best available techniques (BAT) reference document for the production of cement, lime and magnesium oxide - reference document, 506 p. - http://eippcb.jrc.ec.europa.eu/ reference/BREF/CLM_Published_def.pdf

European Commission (2017) Best available techniques (BAT) reference document for the non-ferrous metals industries - reference document, 1233 p. - http://eippcb.jrc.ec.europa.eu/reference/BREF/ NFM/JRC107041_NFM_bref2017.pdf

European Commission (2018) Proposal for a regulation of the european parliament and of the council establishing the Neighbourhood, Development and International Cooperation Instrument. Communication COM (2018) 460. https://eur-lex.europa.eu/legalcontent/EN/TXT/PDF/?uri=CELEX:52018PC0460\&from=EN

European Commission (2020) Critical Raw materials resilience: charting a path towards greater security and sustainability. COM (2020) 474. https://ec.europa.eu/docsroom/documents/42849.

European Parliament (2021) European parliament resolution of 21 January 2021 on reforming the EU list of tax havens (2020/2863(RSP)). https://www.europarl.europa.eu/doceo/ document/TA-9-2021-0022_EN.html.
European Union (2020) Consolidated version of the Treaty on European Union 2016/C 202/1 - Online version: https://eur-lex.europa.eu/legalcontent/EN/TXT/?uri=OJ:C:2016:202:TOC, accessed 03/09/2020

EY (2020) - Top 10 business risks and opportunities - 2020 - Online article: https://www.ey.com/en gl/mining-metals/10-businessrisks-facing-mining-and-metals. Accessed 20/08/2020.

Franks DM, Stringer M, Torres-Cruz LA, Baker E, Valenta R, Thygesen K, Matthews A, Howchin J, Barrie S (2021) Tailings facility disclosures reveal stability risks. Scientific Reports, [online] 11(1). Available at: https://www.nature.com/articles/s41598-021-84897-0.

Garbarino E., Orveillon G., Saveyn H. G. M., Barthe P., Eder P. (2018). Best Available Techniques (BAT) Reference Document for the Management of Waste from Extractive Industries in accordance with Directive 2006/21/EC. Report, 694 p.. European Commission. https://ec.europa.eu/environment/pdf/waste/mining/ MWEI\%20BREF.pdf

G8 (2007) Growth and responsibility in the world economy, Summit Declaration, Heiligendamm, June 7, 2007. Official declaration. http://www.g8.utoronto.ca/summit/2007heiligendamm/g8-2007economy.html

GAIN (Global Aggregate Information Network) (2014) Notes on GAIN Meeting and IOQ/ASPASA Conference in Cape Town on April 1115, 2016.

Halada K, Shimada M, Ijima K (2008) Forecasting of the consumption of metals up to 2050 - materials transactions, Vol. 49, No. 3 (2008) pp. 402 to 410 - https://www.jstage.jst.go.jp/article/matertrans/49/3/49 ML200704/_pdf/-char/en

Hammond TG (2012) Resolving hybrid conflicts: the Bougainville story Foreign Policy Journal - http://www.foreignpolicyjournal.com/ 2012/12/22/resolving-hybrid-conflicts-the-bougainville-story/

Hilpert HG, Mildner SA (2013) Fragmentation or Cooperation in Global Resource Governance? A Comparative Analysis of the Raw Materials Strategies of the G20 - Stiftung Wissenschaft und Politik German Institute for International and Security Affairs, Bundesanstalt für Geowissenschaften und Rohstoffe (Berlin, Germany) - http://www.swp-berlin.org/en/publications/swpresearch-papers/swp-research-paper-detail/article/raw_materials_ strategies_of_the_g20.html

Hund K, La Porta D, Fabregas TP, Laing T, Drexhage J (2020) Minerals for climate action: the mineral intensity of the clean energy transition - report, 112 p. - The World Bank Group - http://pubdocs. worldbank.org/en/961711588875536384/Minerals-for-ClimateAction-The-Mineral-Intensity-of-the-Clean-Energy-Transition.pdf

ICMM (2016) Making a positive contribution to the SDGs. Online interactive guidance document on how mining and metals connect with the SDGs. http://www.icmm.com/sdg.

ICMM. (2020). Role of mining in national economies: Mining Contribution Index. 5th edition - Report, $15 \mathrm{p}$.

International Copper Study Group (ICSG) (2020) The World Copper Factbook 2019. http://www.icsg.org/index.php/component/ jdownloads/finish/170/2965 materiams

Jacobs JA, Lehr JH, Testa SM (2014) Acid mine drainage, rock drainage, and acid sulfate soils: causes, assessment, prediction, prevention, and remediation - Handbook, 520 p. Wiley - ISBN: 978-0-47048786-0

Jain RK, Cui Z, Domen JK (2016) Environmental impact of mining and mineral processing. In: Book. Elsevier

Kesler S. E., Simon A. C. (2015). Mineral resources, economics and the environment - Boo, 446 p. 6 Cambridge University Press

Kharas H (2017) The unprecedented explosion of the global-middle class - an update - Brookings Institute, Global Economy \& Development Working Paper 100 -

Lane A (2020) Europe clamps down on tax havens, but not all are on board. Forbes. [online] 30 May. Available at: https://www.forbes. com/sites/alasdairlane/2020/05/30/europe-clamps-down-on-tax- 
havens-but-not-all-are-on-board/?sh=7a7f32122943. Accessed 8 Mar. 2021

London Metals Exchange (LME) (2020) LME physical copper specifications. Online information: https://www.lme.com/en-GB/Metals/ Non-ferrous/Copper/Physical, accessed on 01/09/2020.

Lottermoser B (2017) Predictive environmental indicators in metal mining. In: Book. Springer. https://doi.org/10.1007/978-3-319-42731-7_1

Martin J. Clifford, Saleem H. Ali, Kazuyo Matsubae, (2019) Mining, land restoration and sustainable development in isolated islands: An industrial ecology perspective on extractive transitions on Nauru. Ambio 48 (4):397-408

Marychurch JM, Stoianoff NP (2006) Blurring the lines of environmental responsibility: how corporate and public governance was circumvented in the Ok Tedi Mining Limited disaster. In: 61st Annual ALTA Conference - Legal Knowledge: Learning, Communicating and Doing Lindfield. Australasian Law Teachers Association (ALTA) Secretariat, Australia

Maxwell Stamp PLC, The World Gold Council (2015) The social and economic impacts of gold mining - Report, 38 p. - http://www. mining.com/wp-content/uploads/2015/06/The-social-andeconomic-impacts-of-gold-mining-june2015.pdf

May RJ (1996) The situation on Bougainville: implications for Papua New Guinea, Australia and the region - Australian Parliamentary Research Service - Department of the Parliamentary Libary. Australian Parliament, Canberra

McDaniel CN, Gowdy JM (2000) Paradise for sale: A parable of nature. University of California Press, Berkeley

Mckenzie Valley Review Board (2013) Report of environmental assessment and reasons for Decision Giant Mine Remediation Project Report, 245 p. - www.reviewboard.ca/upload/project_document/ EA0809-001_Giant_Report_of_Environmental_Assessment_June 20_2013.PDF

Mining.com (2020) Monster rally adds $\$ 250$ billion to global top 50 mining companies. Online article: https://www.mining.com/top50-biggest-mining-companies/, accessed 2020/08/18.

Nicholls C. C. (1999). The Bre-X hoax: a south-east Asian bubble. The Canadian Business Law Journal, vol. 32, $\mathrm{n}^{\circ} 2$.

Norges Bank Investment Management. (2019). The fund. [online] Available at: https://www.nbim.no/ []

OECD (2019) Global Material Resources Outlook to 2060: Economic Drivers and Environmental Consequences - Report, 214 p. OECD Publishing, Paris. 10.1787/9789264307452-en

OECD (2021). Base erosion and profit shifting - OECD BEPS. [online] Available at: https://www.oecd.org/tax/beps/. Accessed 8 Mar. 2021

Ontario Securities Commission (2011) National instrument 43-101 Standards of Disclosure for Mineral Projects - Regulation, 44 P. http://www.osc.gov.on.ca/en/SecuritiesLaw ni 20110624 43101 mineral-projects.htm

Perger J (2020) Wirtschaftsmächte auf den metallischen Rohstoffmärkten - Ein Vergleich von China, der EU und den USA (Economic power centres on the metals markets). DERA Rohstoffinfomationen 46 (in German). Deutsche Rohstoffagentur (DERA, Berlin).

Purvis B, Mao Y, Robinson D (2019) Three pillars of sustainability: in search of conceptual origins. Sustain Sci 14:681-695. https://doi. org/10.1007/s11625-018-0627-5

Randall K (2020) Bid to save Alaskan wild salmon receives surprise boost from Trump Jr. Newspaper article. The Guardian, 2020/08/ 08. https:/www.theguardian.com/environment/2020/aug/08/trumpjr-wild-salmon-alaska-bristol-bay

Reichl C, Schatz M (2020) World Mining Data 2020 - Statistical handbook, 265 p. - Austrian Ministry for Agriculture, Regions and Tourism. https://www.world-mining-data.info/wmd/downloads/ PDF/WMD2020.pdf

S\&P Global (2018) World exploration trends - a special report from S\&P Global Market Intelligence for the PDAC International Convention.
https://pages.marketintelligence.spglobal.com/World-ExplorationTrends-Report-2018-MS.html

S\&P Global (2019) World exploration trends - a special report from S\&P Global Market Intelligence for the PDAC International Convention. https://www.spglobal.com/marketintelligence/en/news-insights/ research/report-world-exploration-trends-2019

Schipper BW, Lina H, Melonia MA, Wansleebend K, Heijungs R, Van der Voet E (2018) Estimating global copper demand until 2100 with regression and stock dynamics. Resources, Conservation \& Recycling 132(2018):28-36

Schodde R (2019) Role of technology and innovation for identifying and growing economic resources. Presentation given at the AMIRA International's 12th Biennial Exploration Managers Conference, Hunter Valley Australia. MINEX CONSULTING. [online] Minexconsulting.com. Available at: https://minexconsulting.com/ role-of-technology-and-innovation-for-identifying-and-growingeconomic-resources/. Accessed 4 Mar. 2021

Silva Rotta LH, Alcântara E, Park E, Galante NR, Nina LY, Bernardo N, Gonçalves Mendes TS, Souza Filho CR (2020) The 2019 Brumadinho tailings dam collapse: possible cause and impacts of the worst human and environmental disaster in Brazil. Int J Appl Earth Obs Geoinformation 90:102119. https://doi.org/10.1016/j.jag. 2020.102119

Tercero Espinoza L, Soulier M, Haag S. (2016) Visualizing global trade flows of copper, an examination of copper contained in international trade flows in 2014 - Working Paper Sustainability and Innovation No. S 03/2016, 22 p. - http://publica.fraunhofer.de/starweb/servlet. starweb?path=epub.web\&search=N-393754

U.S. Geological Survey (2020) Mineral commodity summaries 2020: U.S. Geological Survey, 200 p., https://doi.org/10.3133/mcs2020.

UN Environment (2019) Global mercury assessment. Report, 60 p. UN Environment Programme, Chemicals and Health Branch Geneva, Switzerland. https://wedocs.unep.org/bitstream/handle/20.500. 11822/27579/GMA2018.pdf?sequence=1\&isAllowed=y

UN International Resource Panel (2011) Decoupling natural resource use and environmental impacts from economic growth, a report of the Working Group on Decoupling to the International Resource Panel. Fischer-Kowalski, M., Swilling, M., von Weizsäcker, E.U., Ren, Y., Moriguchi, Y., Crane, W., Krausmann, F., Eisenmenger, N., Giljum, S., Hennicke, P., Romero Lankao, P., Siriban Manalang, A., Sewerin, S. - UNEP (Nairobi, Kenya)

UN International Resource Panel (2013a) Environmental risks and challenges of anthropogenic metals flows and cycles - a report of the Working Group on the Global Metal Flows to the International Resource Panel. van der Voet, E.; Salminen, R.; Eckelman, M.; Mudd, G.; Norgate, T.; Hischier, R. - UNEP (Nairobi, Kenya) http://www.unep.org/resourcepanel/Portals/24102/PDFs/ Environmental_Challenges_Metals-FullReport_150dpi_130923. pdf

UN International Resource Panel (2013b) Metal recycling: opportunities, limits, infrastructure - a report of the Working Group on the Global Metal Flows - Reuter M., Hudson C., Van Schaik A., Heiskanen K., Meskers C., Hagelüken C. - UNEP (Nairobi, Kenya) - http://apps. unep.org/piwik/download.php?file=/publications/pmtdocuments/Meta1\%20Recycling\%200pportunities, \%20Limits,\% 20Infrastructure-2013Metal_recycling.pdf

UN International Resource Panel (2020a) Material zoom - the hidden elements of working from home amidst COVID - YouTube video - https://www.youtube.com/watch?reload=9\&v=L4yfq_wL9fY

UN International Resource Panel (2020b) Mineral resource governance in the 21st century: gearing extractive industries towards sustainable development. In: Ayuk ET, Pedro AM, Ekins P, Gatune J, Milligan B, Oberle B, Christmann P, Ali S, Kumar SV, Bringezu S, Acquatella J, Bernaudat L, Bodouroglou C, Brooks S, Burgii Bonanomi E, Clement J, Collins N, Davis K, Davy A, Dawkins K, Dom A, Eslamishoar F, Franks D, Hamor T, Jensen D, Lahiri- 
Dutt K, Petersen I, Sanders ARD (eds) A Report by the International Resource Panel. United Nations Environment Programme, Nairobi, Kenya https://www.resourcepanel.org/file/1484/download?token= $902 \mathrm{uRy} 2 \mathrm{~h}$

United Nations (2016) Transforming our world: the 2030 Agenda for Sustainable Development - Resolution adopted by the General Assembly on 25 September 2015 - http://www.un.org/ sustainabledevelopment/sustainable-development-goals/

United Nations, Department of Economic and Social Affairs, Population Division (2018) World Urbanization Prospects: The 2018 Revision, Online Edition.

United Nations, Department of Economic and Social Affairs, Population Division (2019) World Population Prospects: The 2019 Revision. Online Edition

Verburg R, Bezuidenhout N, Chatwin T, Ferguson K (2009) The Global Acid Rock Drainage Guide (GARD Guide). Mine Water Environ (2009) 28:305-310. DOI https://doi.org/10.1007/s10230-009-00784 (see also the GARD Wiki: http://www.gardguide.com/index.php? title=Summary\#Introduction).

Vidal O, Weihed P, Hagelüken C, Bol D, Christmann P, Arndt N (2013) ERA-MIN Research Agenda - ERA-MIN, The European Research Area Network (ERA-NET) on the Industrial Handling of Raw Materials for European Industries - (Coordinator: CNRS - the French Research Council, Paris, France) - http://hal-insu.archivesouvertes.fr/docs/00/91/76/53/PDF/roadmap10.pdf
Vidal-Legaz B, Blengini GA, Mathieux F, Latunussa CEL, Mancini L, Nita V, Hamor T, Ardente F, Nuss P, Torres de Matos C, Wittmer D, Talens PL, Garbossa E, Pavel C, Alves DP, Blagoeva D, Bobba S, Huismans J, Eynard U, Di Persio F, Dos Santos Gervasio H, Ciupagea C, Pennington D (2018) European Innovation Partnership on raw materials: raw materials scoreboard - Report, 122 p. European Commission, Directorate General Joint Research Centre - ISBN 978-92-79-89745-0. https://doi.org/10.2873/08258

Weinberger K, Rankine H, Amanuma N, Surendra L, Van Hull HV, Foran T, Reyes R, Malik A, Murray J (2015) Integrating the three dimensions of sustainable development: a framework and tools. In: Report, 33p. Pacific (UNESCAP), United Nations Economic and Social Commission for Asia and the Pacific.

World Bank (2021) World development indicators. [online] Available at: https://datacatalog.worldbank.org/dataset/world-developmentindicators. Accessed 20 Feb. 2021.

Zorn S (2018) Despite our best intentions: Papua New Guinea's Ok Tedi mine and the limits of expert advice. Miner Econ 31:13-21. https:// doi.org/10.1007/s13563-017-0111-1

Publisher's note Springer Nature remains neutral with regard to jurisdictional claims in published maps and institutional affiliations. 